\title{
Program Cost and Schedule Baseline Revision 5
}

(A00000000-00811-1701-00001)

September 1995

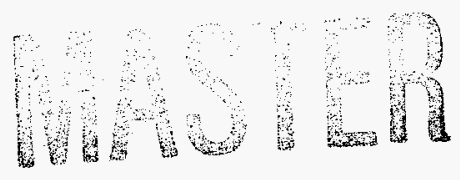

U.S. Department of Energy Office of Civilian Radioactive Waste Management Washington, DC 20585

DISTRIBUTION OF THIS DOCUMENT IS UNLIMITED 


\section{DISCLAIMER}

Portions of this document may be illegible in electronic image products. Images are produced from the best available original document. 


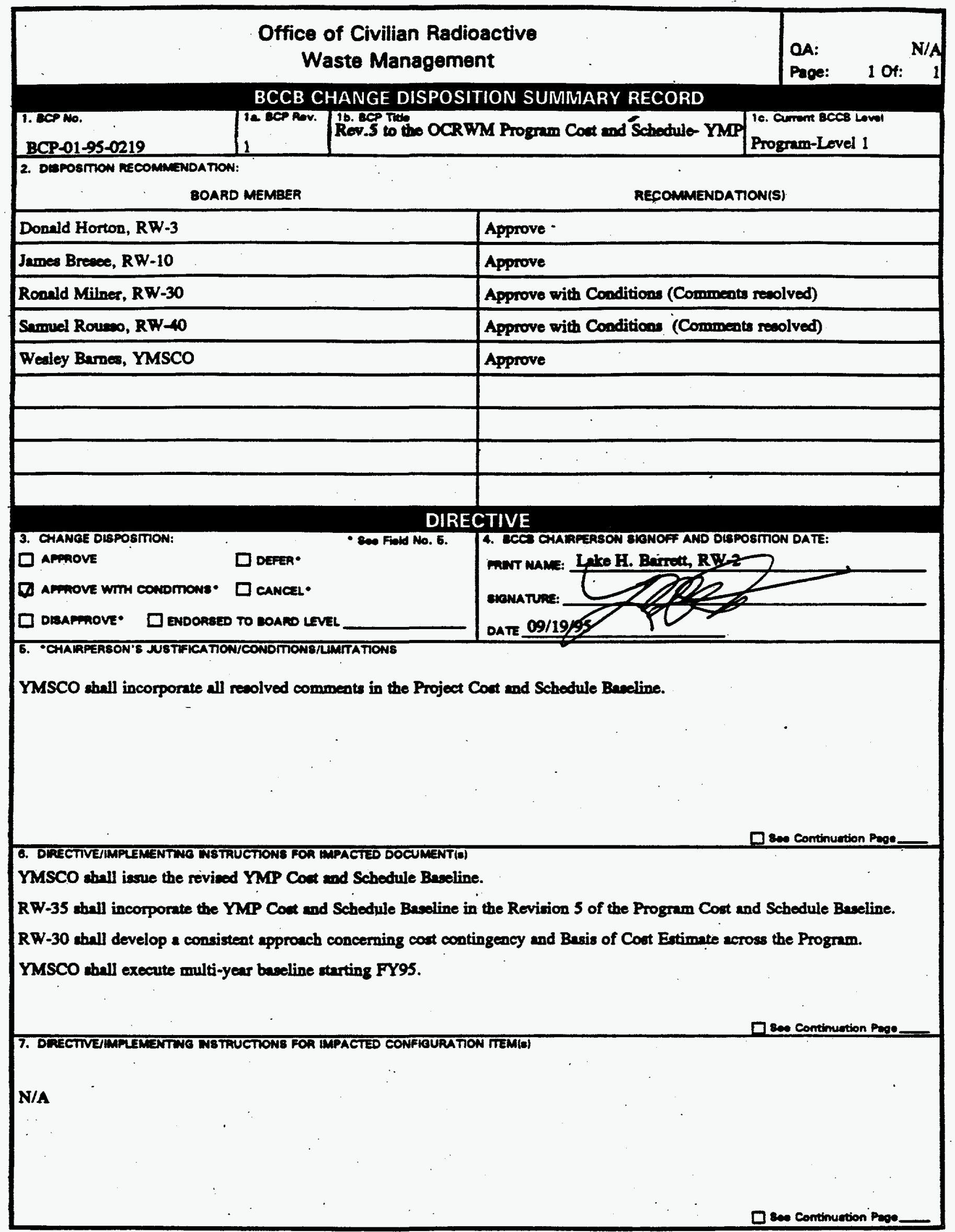




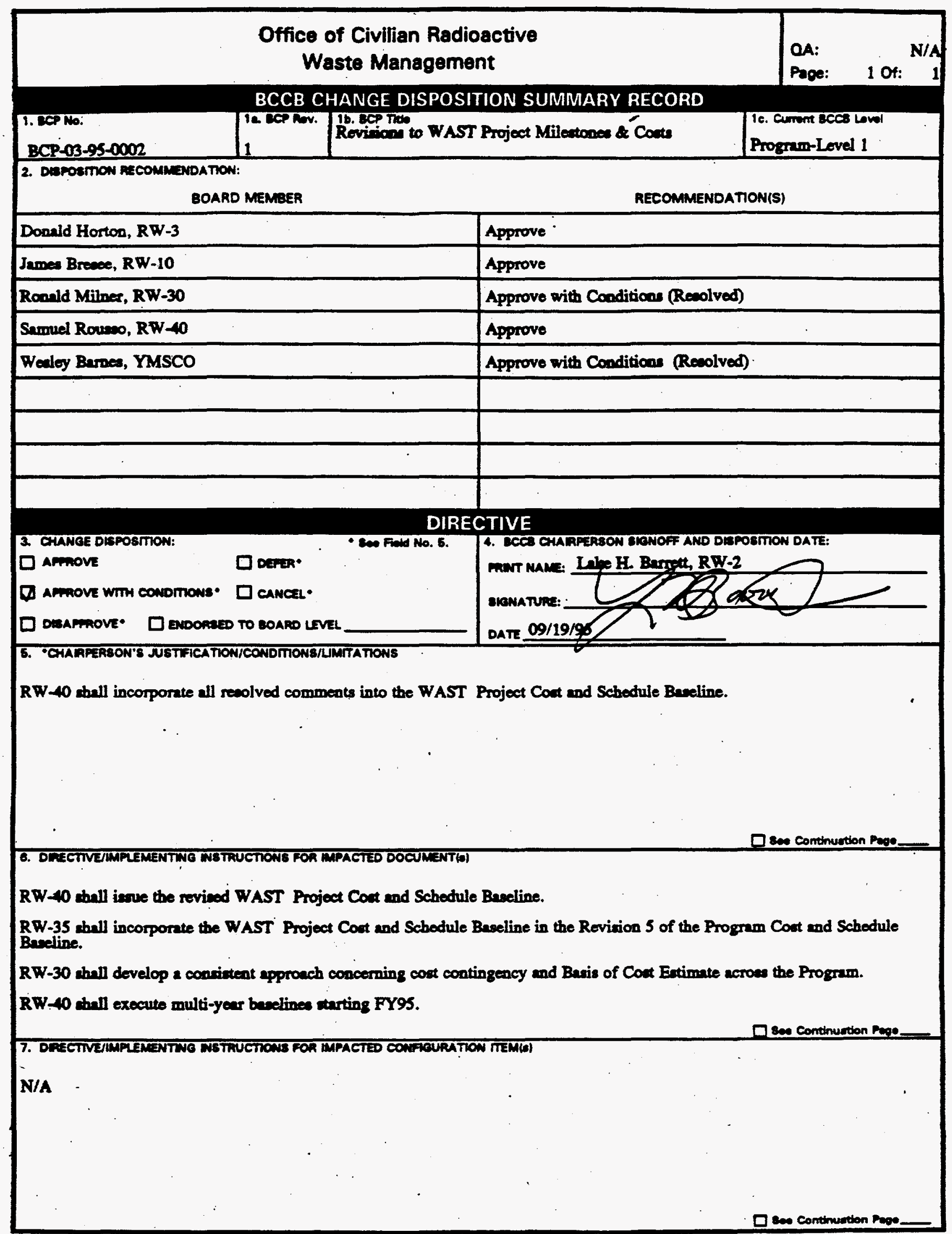




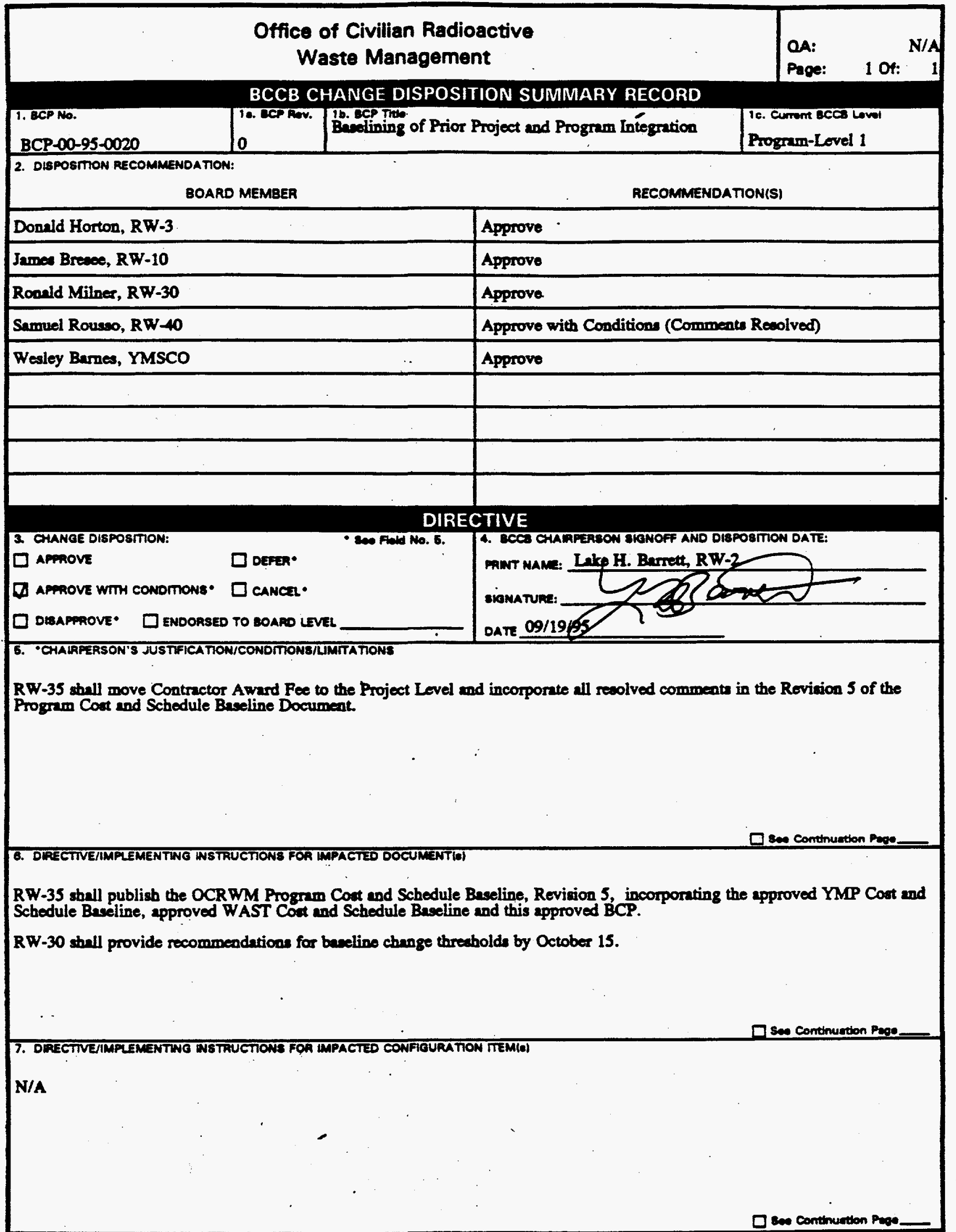




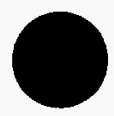

\section{OFFICE OF CIVILIAN RADIOACTIVE WASTE MANAGEMENT PROGRAM CHANGE CONTROL BOARD REVISION/CHANGE RECORD}

(1) DOCUMENT NUMBER: DOE/RW-0253

(2) DOCUMENT TITLE: PROGRAM COST AND SCHEDULE BASELINE

\begin{tabular}{|c|c|c|c|}
\hline $\begin{array}{l}\text { (3) } \\
\text { REVISION } \\
\text { DATE/ } \\
\text { NUMBER }\end{array}$ & $\begin{array}{l}\text { (4) } \\
\text { DCP/BCP } \\
\text { NUMBER }\end{array}$ & REVISION/CHANGE DESCRIPTION & $\begin{array}{l}\text { (6) } \\
\text { PAGES } \\
\text { AFFECTED }\end{array}$ \\
\hline $\begin{array}{l}3 / 11 / 91 \\
\text { REV. } 1\end{array}$ & 32 & $\begin{array}{l}\text { This complete revision incorporates the initial cost baseline, } \\
\text { updated schedule information, and DOE Notice } 4700.4 \\
\text { guidance. }\end{array}$ & ALL \\
\hline $\begin{array}{l}11 / 1 / 91 \\
\text { REV. } 2\end{array}$ & 50 & $\begin{array}{l}\text { This includes the addition of the YM Site Characterization } \\
\text { Project (YMP) annualized, escalated, Total Project Cost by } \\
\text { third level WBS (Table A-1), a revision to the YMP Summary } \\
\text { of Cost Baseline Estimates (Table } 1 \text { and Page 5), the } \\
\text { modification of one Level } 0 \text { Milestone title (KD-3 on pages } 9 \text {, } \\
11 \text {, and B-8), the deletion of one Level } 1 \text { Milestone (RR569 } \\
\text { on page B-8), the revision of one Level } 1 \text { Milestone } \\
\text { Description (RM656 on page } 11 \text { and page B-9), the revision } \\
\text { of the Milestone Completion Criteria on two Milestones } \\
\text { (R6610 and RM656 on page B-9), and a revision to one WBS } \\
\text { element name (ESF in Table 1, Table A-1, and page B-7). }\end{array}$ & \\
\hline $\begin{array}{l}9 / 20 / 92 \\
\text { REV. } 3\end{array}$ & 58 & $\begin{array}{l}\text { This revision to both the YMP and MRS Project adds } 24 \\
\text { Milestones, deletes } 12 \text { Milestones ( } 6 \text { of which because they } \\
\text { were completed), updates } 15 \text { Milestone dates, changes } 14 \\
\text { Milestone Descriptions, and modifies } 18 \text { Completion Criteria. } \\
\text { Milestones were changed to reflect the enacted FY } 1992 \\
\text { budget and the current technical program, In addition, MRS } \\
\text { Project Milestones that are Key Decisions as defined by DOE } \\
4700.1 \text { have been identified and Energy System Acquisition } \\
\text { Review (ESAR) Milestones have been added for those years } \\
\text { in which Key Decisions do not occur. The Yucca Mountain } \\
\text { Project (YMP) Funding Profile in the Cost Baseline (Table A- } \\
\text { 1) has been changed to reflect the FY } 1992 \text { enacted budget } \\
\text { plus carryover from prior years, and the Out Year Funding } \\
\text { Estimates from } 1993 \text { through } 2001 \text { have been deleted pending } \\
\text { enactment of the FY } 1993 \text { appropriation and receipt of FY } \\
1994 \text { OMB passback. Also, Milestones and cost categories } \\
\text { have been reordered to be consistent with the new OCRWM } \\
\text { Program Work Breakdown Structure (DOE/RW-0325P), and } \\
\text { the PCSB administrative procedures (pages 1-14) have been } \\
\text { modified to be consistent with recent revisions to other } \\
\text { programmatic documents. }\end{array}$ & ALL \\
\hline
\end{tabular}




\section{OFFICE OF CIVILIAN RADIOACTIVE WASTE MANAGEMENT \\ PROGRAM CHANGE CONTROL BOARD \\ REVISION/CHANGE RECORD}

(1) DOCUMENT NUMBER: DOE/RW-0253

(2) DOCUMENT TITLE: PROGRAM COST AND SCHEDULE BASELINE

(3)

(3)

REVISION

DATE/

NUMBER

$4 / 13 / 9$

REV. 3/DCN 01

\begin{tabular}{|l|l|} 
& \\
\hline $11 / 21 / 94$ & BCP-00- \\
REV. 4 & $94-0005$
\end{tabular}

$\mathrm{DCP} / \mathrm{BCP}$

NUMBER

BCP.00-
(5)

This BCP generated a Document Change Notice (DCN) which

removed the rail/barge cast system development and its

milestones, removed the existing technology cask acquisition

program and its milestones, and revised the GA-4/9 cask system development milestone.

This revision replaces the OCRWM cost and schedule baselines with interim cost and schedule baselines reflecting the current Program Approach. This Approach added the development of the Multi-Purpose Canister (MPC) System, deleted Monitored Retrievable Storage (MRS) facility development, added the initial deployment (in 1998) of MPCs to utility sites for on-site storage, delayed a fully operational Transportation System to 2010, rephased YMP testing, and increased the geological repository waste retrieval period to approximately 100 years from initiation of emplacement. The MRS Project was changed to the WAST Project. The MRS Project TPC of $\$ 1,332$ million was replaced with an the WAST Project interim TPC of $\$ 686.0$ million. The Yucca Mountain Site Characterization Project TPC of $\$ 6.319$ billion was replaced with an interim TPC of $\$ 4.950$ billion References to DOE and OCRWM documents and OCRWM organizational titles were updated.
(6)

PAGES

AFFECTED

Pages 1, 7,9, 11, D-1, D-2,

D-3

ALL 
OFFICE OF CIVILIAN RADIOACTIVE WASTE MANAGEMENT

PROGRAM CHANGE CONTROL BOARD

REVISION/CHANGE RECORD

(1) DOCUMENT NUMBER: DOE/RW-0253

(2) DOCUMENT TITLE: PROGRAM COST AND SCHEDULE BASELINE

(3)

REVISION

DATE/

NUMBER
(4)

DCP/BCP

NUMBER

BCP-01-

95-0219

REV. 5
(5)

(6)

PAGES

AFFECTED
BCP-03-

95-0002

BCP-00-

95-0020
This revision incorporates three BCPs and replaces the interim cost and schedule baselines with the cost and schedules based on the detailed review and update of the Yucca Mountain Site Characterization Project (YMP) and the WAST Project cost and schedule baselines. It also includes the cost and schedule for the Program Integration elements of the Program and the historical costs for inactive Program elements. It updates the level of the schedule milestones based on new criteria. A Total Program Cost for the Civilian Radioactive Waste Management Strategic System of $\$ 8,545$ million, for control by the ESAAB, was established. The YMP interim Total Project Cost (TPC) of $\$ 4,950$ million was replaced with a TPC of $\$ 4,977$ million.

The WAST interim TPC of $\$ 686$ million was replaced with a TPC of $\$ 752$ million. A TPC for Quality Assurance of $\$ 209$ million was established. A TPC for Program Management and Integration of $\$ 1,093$ million was established. A TPC for Human Resources and Administration of $\$ 269$ million was established. Procedural sections were removed from this document and replaced with references to their new location. 


\section{Table of Contents}

Page

1. INTRODUCTION $\ldots \ldots \ldots \ldots \ldots \ldots \ldots \ldots \ldots \ldots \ldots \ldots \ldots \ldots \ldots \ldots$

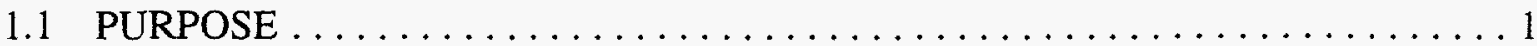

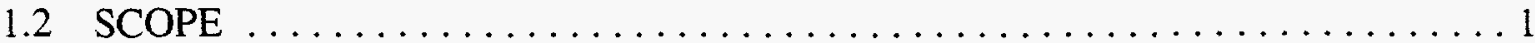

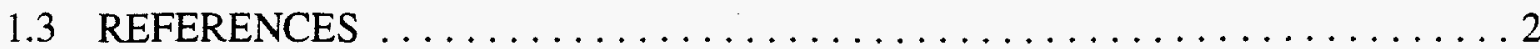

1.4 RELATIONSHIP TO OTHER OCRWM COST/SCHEDULE INFORMATION . . . 2

2. COST AND SCHEDULE BASELINE DATA $\ldots \ldots \ldots \ldots \ldots \ldots \ldots \ldots \ldots$

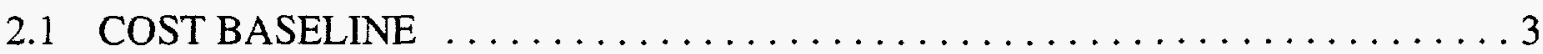

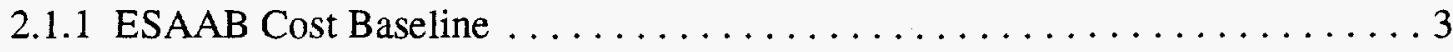

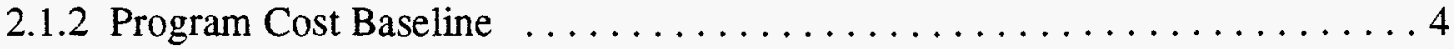

2.2 SCHEDULE BASELINE $\ldots \ldots \ldots \ldots \ldots \ldots \ldots \ldots \ldots \ldots \ldots \ldots \ldots \ldots$

2.2.1 ESAAB Schedule Baseline $\ldots \ldots \ldots \ldots \ldots \ldots \ldots \ldots \ldots \ldots \ldots \ldots$

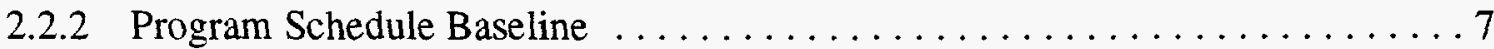

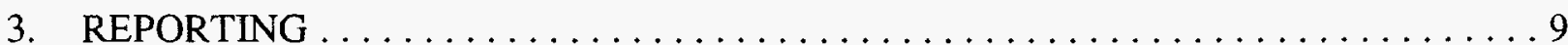

4. MONITORING AND CONTROL $\ldots \ldots \ldots \ldots \ldots \ldots \ldots \ldots \ldots \ldots \ldots$

4.1 MONITORING REQUIREMENTS $\ldots \ldots \ldots \ldots \ldots \ldots \ldots \ldots \ldots \ldots$

4.2 BCCB THRESHOLDS $\ldots \ldots \ldots \ldots \ldots \ldots \ldots \ldots \ldots \ldots \ldots \ldots$

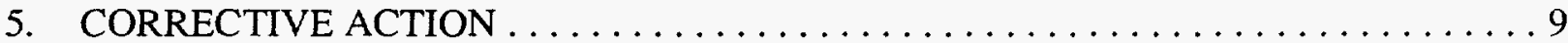

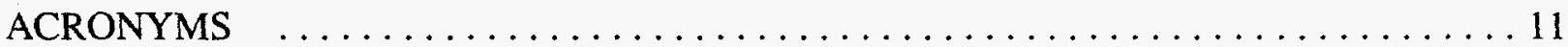

APPENDIX A - ANNUALIZED COST BASELINE FOR THE YUCCA MOUNTAIN SITE CHARACTERIZATION PROJECT $\ldots \ldots \ldots \ldots \ldots$ A-1

APPENDIX B - PROGRAM SCHEDULE BASELINE - YUCCA MOUNTAIN SITE CHARACTERIZATION PROJECT MILESTONES . . . . . . . . . . B-1

APPENDIX C - ANNUALIZED COST BASELINE FOR THE WASTE ACCEPTANCE, STORAGE AND TRANSPORTATION PROJECT (WAST) . . . . . . . . C-1

APPENDIX D - PROGRAM SCHEDULE BASELINE - WAST PROJECT MILESTONES 
Table of Contents (Continued)

\section{Page}

APPENDIX E - ANNUALIZED COST BASELINE FOR PROGRAM

INTEGRATION $\ldots \ldots \ldots \ldots \ldots \ldots \ldots \ldots \ldots \ldots \ldots \ldots \ldots \ldots \ldots$ E-1

APPENDIX F - PROGRAM SCHEDULE BASELINE - PROGRAM INTEGRATION

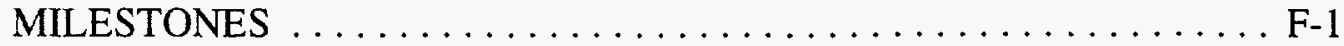

APPENDIX G - LONG-TERM REFERENCE SCHEDULE $\ldots \ldots \ldots \ldots \ldots \ldots \ldots$ G-1 


\section{List of Figures}

Page

1. CRWMS Schedule Baseline $\ldots \ldots \ldots \ldots \ldots \ldots \ldots \ldots \ldots$ 


\section{List of Tables}

Page

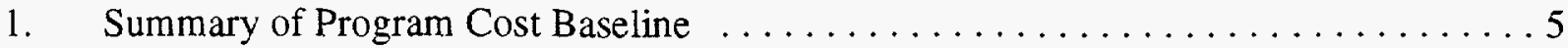

2. Criteria for Inclusion of Milestones in the PCSB $\ldots \ldots \ldots \ldots \ldots \ldots \ldots \ldots$ 


\section{INTRODUCTION}

\subsection{PURPOSE}

The purpose of this document is to establish quantitative expressions of proposed costs and schedule to serve as a basis for measurement of Program performance. It identifies the components of the Program Cost and Schedule Baseline (PCSB) that will be subject to change control by the Executive (Level 0) and Program (Level 1) Baseline Change Control Boards (BCCBs) and establishes their baseline values. The Program technical baseline is contained in the Civilian Radioactive Waste Management System (CRWMS) Requirements Document (CRD) and the System Requirement Documents (SRDs) for the individual system elements.

Changes to the PCSB will be approved by the Program Baseline Change Control Board (PBCCB). In addition to the PBCCB, the Energy System Acquisition Advisory Board Baseline Change Control Board (ESAAB BCCB) will perform control functions relating to Total Project Cost (TPC) and major schedule milestones for the Yucca Mountain Site Characterization Project, the Waste Acceptance, Storage and Transportation (WAST) Project (formerly Monitored Retrievable Storage (MRS) Project), and Program Integration element. Additional information on how the PCSB is integrated into the OCRWM management system is contained in the Program Management System (PMS) Manual.

\subsection{SCOPE}

The PCSB establishes baseline values for the Yucca Mountain Site Characterization Project cost and schedule through submittal of the repository license application (LA) to the Nuclear Regulatory Commission (NRC). The WAST Project cost and schedule baseline applies to a WAST Project scope which includes the development of Multi-Purpose Canisters (MPCs); assumes no MRS Facility, but does not preclude a Federal Interim Central Storage (FICS) Facility if siting and funding become available; and provides for a fully operational Transportation System by 2010 . The cost baseline for the WAST Project is established through FY 2000 and covers the initial deployment in 1998 of MPCs to Purchaser sites for at-reactor storage and the production of an initial set of MPCs (canister only) to be deployed. The PCSB establishes baseline values for the OCRWM Program Integration element, through the latest end point of the projects, to provide management oversight, guidance, direction and review in the areas of quality assurance, system engineering, regulatory compliance and program management as defined in the Program Work Breakdown Structure Dictionary.

The PCSB also contains a long-term reference schedule from the end of the Yucca Mountain Site Characterization Project baseline period through completion of the Program's life cycle (i.e., the decommissioning of the Mined Geologic Disposal System (MGDS)). For the WAST Project, it extends from FY 2001 to FY 2010, the date the Transportation System will be fully operational. The primary purpose of the long-term reference schedule is to establish a schedule which is consistent with the scope and time frame of the Program's technical baseline. This long-term reference schedule will be used largely to analyze the schedule impacts associated with change proposals to the technical baseline. By maintaining a Program long-term reference schedule, Program schedule changes resulting from changes in the technical baseline can be formally 
documented. The long-term reference schedule will not be subject to ESAAB BCCB review, but will be controlled only by the PBCCB.

OCRWM regularly prepares cost estimates that extend beyond the end of the cost baseline. The source for all such cost estimates will be the most recent approved Total System Life Cycle Cost (TSLCC) analysis performed in conjunction with the annual fee adequacy assessment.

\subsection{REFERENCES}

a. U.S. Department of Energy, Office of the Associate Deputy Secretary for Field Management, Memorandum, subject "Designation of the Office of Civilian Radioactive Waste Management (OCRWM) System as a Strategic System," May 31, 1995.

b. U.S. DOE Order 4700.1, Project Management System, March 6, 1987.

c. U: S. DOE/RW-0043, Program Management System Manual, Rev. 5, January 1993.

d. U.S. DOE/RW-0409, Program Baseline Change Control Procedure, Rev. 1, DCN01, December 1994.

e. U.S. DOE/RW-0325P, Program Work Breakdown Structure Dictionary, September 1995.

f. $\quad$ U.S. DOE Order 5100.3, Field Budget Process, August 23, 1984.

\subsection{RELATIONSHIP TO OTHER OCRWM COST/SCHEDULE INFORMATION}

The PCSB is OCRWM's primary mechanism for cost/schedule control and performance measurement. More detailed cost and schedule baselines, subject to change control, shall be maintained at the project level. These other cost and schedule baselines shall support and be subordinate to the PCSB. Other OCRWM management plans that contain costs or schedule milestones shall acknowledge the PCSB as the controlling document.

The PCSB is also the primary source of cost and schedule information released outside OCRWM. The cost baseline may require updating as a result of the budget formulation process. Likewise, budget data, along with related schedule information contained in the PCSB, will be used as input into the TSLCC analysis. The TSLCC analysis is then used as the cost basis to calculate the adequacy of the ongoing fee paid by waste generators/owners into the Nuclear Waste Fund to fully recover the costs of the Program. This information is published in the annual Fee Adequacy Report.

The schedule baseline shall be the basis for externally-released schedule information in the Project Decision Schedule, any amendments to the Mission Plan, and the Mission Implementation Plan. The schedule baseline shall define the reference case schedule for Program budget formulation. Critical path networks that show the major activities and activity relationships for the PCSB shall be maintained and shall define the basis for the baseline milestone dates and costs. 


\section{COST AND SCHEDULE BASELINE DATA}

\subsection{COST BASELINE}

The Program cost baseline is the sum of the Total Project Cost (TPC) of past and current projects and the Program Integration element of the Program. It is subject to independent review and will be changed as necessary to reflect improved cost data, changing assumptions, future budget appropriations, etc.. The work procured by the Program cost baseline is defined in the Program Work Breakdown Structure (WBS). The Program WBS Dictionary contains the detailed breakdown of work scope and products defined for each Program element.

The Program cost baseline is the sum of all TPCs. Annualized costs for current projects and the Program Integration element are shown in the appendices but are not baselined. All costs in the PCSB are expressed in year-of-expenditure dollars. A TPC, as defined in DOE Order 4700.1, includes all development and evaluation costs, operating costs associated with test and evaluation, and plant and capital equipment costs specifically associated with a project through the start of operations. In addition, TPC includes all historical costs as required by DOE Order 5100.3. It is the sum of Total Estimated Cost (TEC) plus all other costs identifiable with the project. TEC is defined in DOE Order 4700.1 as the cost of the project, including the cost of land and land rights, engineering design and inspection costs, direct and indirect construction costs, and initial equipment costs necessary to place the plant or installation in operation, whether funded from operating or plant and capital equipment appropriations. The annualized cost baselines for the Yucca Mountain Site Characterization Project (WBS 1.2), the WAST Project (WBS 3.0), and the Program Integration element (WBS 9.0) are contained in Appendices A, C, and E, respectively, for information only. The WBS cost breakouts in Appendices $\mathrm{A}$ and $\mathrm{C}$ are also for information only.

The responsible organization for the Yucca Mountain Site Characterization Project cost baseline data is the Yucca Mountain Site Characterization Office (YMSCO). The responsible organization for the WAST Project cost baseline data is the Office of Waste Acceptance, Storage and Transportation. The responsible organizations for the Program Integration element cost baseline data are the Offices of Program Management and Integration, Human Resources and Administration, and Quality Assurance. Responsible organizations shall maintain backup information that defines the basis for the cost baseline.

\subsubsection{ESAAB Cost Baseline}

The Total Program Cost controlled by the ESAAB BCCB is $\$ 8.545$ billion consisting of the sum of the Total Project Costs listed in Table 1 which include the currently active Yucca Mountain Site Characterization Project ( $\$ 4.977$ billion), WAST Project ( $\$ 752$ million), and Program Integration Element (\$1.571 billion) and the cancelled (by the Nuclear Waste Policy Amendments Act of 1987) Basalt Site Characterization Project ( $\$ 485$ million), Salt Site Characterization Project $(\$ 519$ million), Technical Support/Analytical Studies ( $\$ 160$ million), and Second Repository Project (\$81 million). 


\subsubsection{Program Cost Baseline}

The costs that shall be controlled by the PBCCB are presented in Table 1. All costs are expressed in year-of-expenditure dollars.

\subsection{SCHEDULE BASELINE}

The schedule baseline is a controlled list of Program milestones that satisfy the criteria described in Table 2. Appendices B, D, and F contain the schedule milestones for the Yucca Mountain Site Characterization Project, the WAST Project, and Program Integration, respectively. The following information is included for each milestone in the schedule baseline:

Milestone Description - A concise description of an event. The milestone description shall be appropriate for release outside DOE. The first word of the milestone description shall be a verb.

Milestone Identification - A unique identification number. The first character of the identification shall be $\underline{R}, \underline{M}, \underline{T}, \underline{W}, \underline{M Z}$, or $\mathbf{P}$ for Repository (Yucca Mountain Site Characterization Project), MRS/MPC, Transportation, Waste Acceptance, Project Management, or Program Integration respectively.

Milestone Responsibility - The cognizant Director responsible for performing the activity associated with the milestone.

Highest-Level Change Control Board - The highest-level change control board shall be specified. All milestones controlled by the ESAAB BCCB will also be controlled by the PBCCB.

Milestone WBS - The work breakdown structure assignment for the activity associated with the milestone. Milestones shall be assigned to Level 2 of the Program WBS and consistent with the Program WBS Dictionary.

Milestone Completion Criteria - A description of the scope of work and required actions which signal the completion of the milestone by the responsible organization. Where applicable, the completion criteria shall identify major prerequisites for the milestone.

Baseline Date - The approved date that shall be used for internal planning and external reporting. 
Table 1. Summary of Program Cost Baseline

(millions of year-of-expenditure dollars)

\begin{tabular}{|c|c|c|}
\hline $\begin{array}{l}\text { Yucca Mountain Site } \\
\text { Characterization Project }\end{array}$ & Total Project Cost ${ }^{(a)}$ & 4,977 \\
\hline WAST Project & Total Project Cost ${ }^{(a)}$ & 752 \\
\hline Quality Assurance & Total Project Cost ${ }^{(a)}$ & 209 \\
\hline $\begin{array}{l}\text { Program Management } \\
\text { and Integration }\end{array}$ & Total Project Cost ${ }^{\text {(a) }}$ & 1,093 \\
\hline $\begin{array}{l}\text { Human Resource } \\
\text { and Administration }\end{array}$ & Total Project Cost ${ }^{\text {(a) }}$ & 269 \\
\hline $\begin{array}{l}\text { BASALT Site } \\
\text { Characterization }\end{array}$ & Total Project Cost ${ }^{(a)}$ & 485 \\
\hline $\begin{array}{l}\text { Salt Site } \\
\text { Characterization }\end{array}$ & Total Project Cost ${ }^{(a)}$ & 519 \\
\hline $\begin{array}{l}\text { Technical Support/ } \\
\text { Analytical Studies }\end{array}$ & Total Project Cost ${ }^{(a)}$ & 160 \\
\hline Second Repository & Total Project Cost ${ }^{(\mathrm{a})}$ & 81 \\
\hline CRWM Strategic System & Total Program Cost $^{(\mathrm{b})}$ & 8,545 \\
\hline
\end{tabular}

a Controlled by Program Baseline Change Control Board.

b. Controlled by ESAAB. 
Table 2. Criteria for Inclusion of Milestones in the PCSB.

Level 0 Milestones are included in the PCSB and are those controlled by the Secretary, acting as Acquisition Executive in the ESAAB process, which meet the following criteria:

1. Start and completion of major activities mandated by law.

2. Major program decision points which are dictated by DOE orders.

3. Energy systems progress reviews (annual review to ESAAB if no level 0 milestone is scheduled).

4. Other specific events designated by the Secretary.

Level 1 Milestones are included in the PCSB and are those controlled by the Director of OCRWM which meet the following criteria:

1. All level 0 milestones prior to submission to the Secretary.

2. Start and completion of major project phases (i.e. ACD, LAD, construction, operations, decommissioning, major fabrication initiation, etc.).

3. Major regulatory compliance actions, including initiation of environmental impact statement scoping, draft environmental impact statement issuance, final environmental impact statement issuance, and certification of compliance submissions.

4. Major crosscutting decisions which require integration between OCRWM projects or with OCRWM/DOE headquarters staff.

5. Major intermediate findings (HLFs) leading to Yucca Mountain site suitability determination and incremental steps to submission of a license application.

6. Completion of major documents and directives which affect the entire program or are transmitted to external agencies, stakeholders, oversight groups.

7. Notice of Proposed Rulemaking, Notice of Intent.

8. Other specific milestones designated by the OCRWM Director. 


\subsubsection{ESAAB Schedule Baseline}

Milestones controlled by the ESAAB BCCB are a subset of the Program schedule milestones contained in Appendices B, D, and F. The schedule milestones for the Yucca Mountain Site Characterization Project that shall be controlled by the ESAAB BCCB are:

Notify State of Site Selection

$8 / 28 / 00$

Approve Repository Final Record of Decision

$9 / 22 / 00$

Issue Site Recommendation Report to President

$9 / 29 / 00$

Submit License Application to NRC

$6 / 29 / 01$

The schedule milestones for the WAST Project that shall be controlled by the ESAAB BCCB are:

Decide to Proceed with MPC Concept

$3 / 1 / 94$

Present WAST Project Energy System Acquisition

Review (ESAR) \#1

$4 / 15 / 94$

Present WAST Project ESAR \#2

$4 / 27 / 95$

Issue MPC EIS Record of Decision

$9 / 26 / 96$

Decision by ESAAB on MPC Fabrication and Deployment

$11 / 17 / 97$

Approval by ESAAB to Continue MPC Fabrication and Deployment

$1 / 31 / 00$

The interim schedule milestone for the Program Integration element that shall be controlled by the ESAAB BCCB is:

Approve ESAAB Program Approach Baseline

$1 / 15 / 96$

\subsubsection{Program Schedule Baseline}

Figure 1 shows all the PCSB milestones that shall be subject to change control. The complete set of schedule baseline milestones for the Yucca Mountain Site Characterization Project, the WAST Project, and the Program Integration element are contained in Appendices B, D, and F, respectively. Appendix $\mathrm{G}$ contains the long-term reference schedule which is not baselined. 


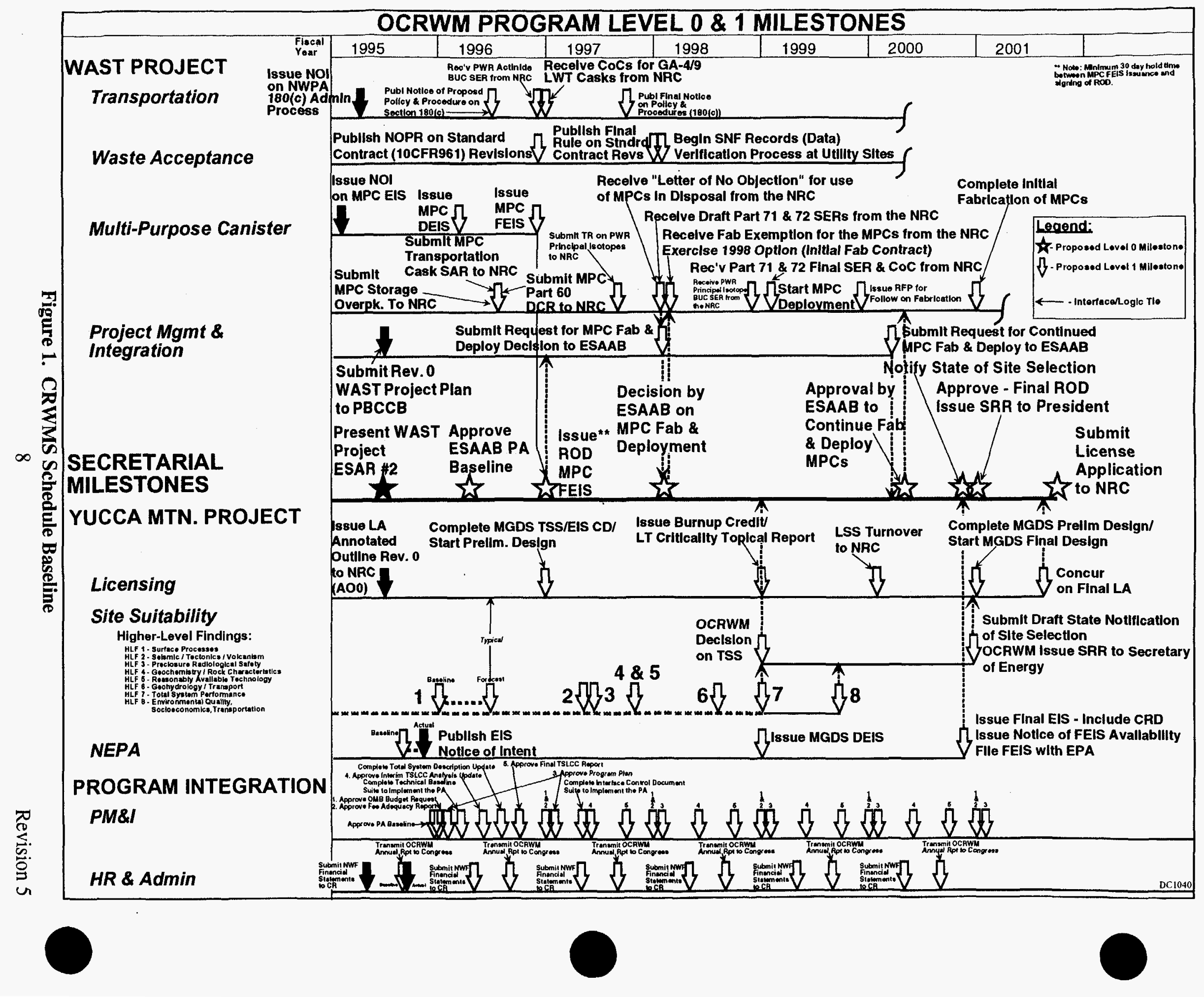




\section{REPORTING}

Program reporting requirements are under revision in response to changing guidance from the Department of Energy and will be included in OCRWM program management documents under development.

\section{MONITORING AND CONTROL}

\subsection{MONITORING REQUIREMENTS}

Program monitoring requirements are under revision in response to changing guidance from the Department of Energy and will be included in OCRWM program management documents under development.

\subsection{BCCB THRESHOLDS}

Thresholds for the BCCBs are contained in the OCRWM Baseline Management Plan.

\section{CORRECTIVE ACTION}

Program corrective action requirements are under revision in response to changing guidance from the Department of Energy and will be included in OCRWM program management documents under development. 
INTENTIONALLY LEFT BLANK

Revision 5 


\section{ACRONYMS}

AE

BCCB

$\mathrm{BCP}$

CDR

CFR

$\mathrm{CoC}$

CRWMS

CY

DEIS

DOE

EA

EFDATE

EIS

EM

ESAAB

ESAR

E,S\&H

ESF

FEIS

FICS

FY

GA

HLF

HLW

$\mathrm{H}, \mathrm{M} \& \mathrm{~S}$

ID

INEL

$\mathrm{KD}$

LA

LWT

MGDS

$M \& O$

MPC

MRS
Acquisition Executive

Baseline Change Control Board

Baseline Change Proposal

Conceptual Design Report

Code of Federal Regulations

Certificate of Compliance

Civilian Radioactive Waste Management System

Calender Year

Draft Environmental Impact Statement

Department of Energy

Environmental Assessment

Effective Date

Environmental Impact Statement

Office of Environmental Management

Energy System Acquisition Advisory Board

Energy System Acquisition Review

Environmental, Safety and Health

Exploratory Studies Facility

Final Environmental Impact Statement

Federal Interim Central Storage

Fiscal Year

General Atomics

Higher Level Finding

High-Level Radioactive Waste

Handling, Maintenance and Supply

Identification Number

Idaho National Engineering Laboratory

Key Decision

License Application

Legal Weight Truck

Mined Geologic Disposal System

Management and Operating Contractor

Multi-Purpose Canister

Monitored Retrievable Storage 


\section{ACRONYMS (Continued)}

NEPA

NOI

NOPR

NRC

NWPA

OCRWM

OMB

OMTS

OPMI

PA

PBCCB

PCS

PCSB

PMD

PMI

PMS

POBCCB

PWBS

QA

RFP

ROD

RW

SAR

SER

SNF

SRD

TBD

TEC

TPC

TS

TSLCC

WAST

WBS

YMP

YMSCO
National Environmental Policy Act

Notice of Inquiry or Intent

Notice of Proposed Rulemaking

Nuclear Regulatory Commission

Nuclear Waste Policy Act

Office of Civilian Radioactive Waste Management

Office of Management and Budget

Operations Management Tracking System

Office of Program Management and Integration

Program Approach

Program Baseline Change Control Board

Project Control System

Program Cost and Schedule Baseline

Program Management Division

Project Management and Integration

Program Management System

Project Office Baseline Change Control Board

Project Work Breakdown Structure

Quality Assurance

Request for Proposal

Record of Decision

Radioactive Waste

Safety Analysis Report

Safety Evaluation Report

Spent Nuclear Fuel

System Requirements Documents

To Be Determined

Total Estimated Cost

Total Project Cost

Transportation System

Total System Life Cycle Cost

Waste Acceptance, Storage and Transportation

Work Breakdown Structure

Yucca Mountain Site Characterization Project

Yucca Mountain Site Characterization Office 


\section{APPENDIX A}

ANNUALIZED COST BASELINE FOR THE YUCCA MOUNTAIN SITE CHARACTERIZATION PROJECT

Revision 5 
INTENTIONALLY LEFT BLANK

Revision 5 


\section{ANNUALIZED COST BASELINE - YUCCA MOUNTAIN SITE CHARACTERIZATION PROJECT (Millions of year-of-expenditure dollars ${ }^{(\mathrm{a})}$ )}

\begin{tabular}{|c|c|c|c|c|c|c|c|c|c|}
\hline WBS Element $^{(b)}$ & $\begin{array}{l}\text { Pre } \\
\text { FY1995 }\end{array}$ & FY1995 & FY 1996 & FY 1997 & FY1998 & FY1999 & FY2000 & FY2001 & TOTAL \\
\hline Systems Engineering & & 9.3 & 15.0 & 17.0 & 17.6 & 15.0 & 10.0 & 5.2 & 89.1 \\
\hline Waste Package & & 9.9 & 13.0 & 14.0 & 17.0 & 17.0 & 14.0 & 10.5 & 95.4 \\
\hline Site Investigations & & 95.4 & 110.0 & 120.0 & 139.7 & 117.0 & 91.0 & 56.3 & 729.3 \\
\hline Repository & & 9.4 & 25.0 & 39.1 & 39.0 & 40.0 & 35.0 & 26.3 & 213.7 \\
\hline Regulatory & & 28.1 & 30.6 & 42.0 & 44.5 & 48.9 & 39.4 & 20.8 & 254.1 \\
\hline Exploratory Studies Facilities & & 121.7 & 103.0 & 103.0 & 81.6 & 84.5 & 39.5 & 23.1 & 556.4 \\
\hline Test Facilities & & 17.4 & 29.5 & 35.1 & 34.0 & 34.0 & 35.5 & 25.1 & 210.6 \\
\hline Project Management & & 21.3 & 16.5 & 17.0 & 17.5 & 18.0 & 18.5 & 14.3 & 123.1 \\
\hline Financial Assistance & & 37.3 & 32.5 & 37.5 & 33.4 & 28.4 & 25.9 & 19.4 & 214.3 \\
\hline Quality Assurance & & 10.2 & 10.5 & 11.0 & 11.6 & 13.0 & 13.5 & 10.1 & 79.9 \\
\hline Information Management & & 15.2 & 25.8 & 26.2 & 24.7 & 25.2 & 24.7 & 18.2 & 160.1 \\
\hline Environment, Safety, \& Health & & 20.2 & 30.0 & 33.5 & 30.5 & 28.0 & 23.5 & 13.5 & 179.2 \\
\hline Institutional & & 4.8 & 5.0 & 5.5 & 6.0 & 6.5 & 6.5 & 4.9 & 39.2 \\
\hline Support Services & & 22.0 & 27.4 & 32.2 & 34.0 & 35.7 & 31.6 & 19.9 & 202.9 \\
\hline Contingency $^{(\mathrm{c})}$ & & 0 & 0 & 0 & 0 & 15.5 & 60.0 & 0 & 75.5 \\
\hline TOTAL $^{(\mathrm{d})}$ & 1,754 & $422^{(\mathrm{e})}$ & 474 & 533 & 531 & 527 & 469 & 267 & 4,977 \\
\hline
\end{tabular}

a. Costs are updated from those approved in BCP-00-94-0005 by replacing FY 1994 funds available to cost ( $\$ 309$ million) with FY 1994 actual costs ( $\$ 280$ million) and replacing the FY 1995 appropriation (\$375 million) with the FY 1995 Project Total Cost including budgeted contractor fees as of June 1995 ( $\$ 422$ million). PreFY 1995 costs are prior year actual costs from January 1983
through FY 1994. FY 1996-FY 2001 costs are from YMP/CM-0015, Project Cost and Schedule Baseline.

b. WBS elements shown are PostFY1992. Detailed records do not exist to translate PreFY1993 costs into PostFY1992 WBS elements.

c. Includes undistributed budget. These contingency values are incorporated within WBS 1.2 .15 originally for facility scoring in the YMP baseline YMP/CM-0015, Revision 5. Analysis has shown such use is infeasible, and therefore this budget is allocated to contingency in this Program baseline.

d. May not add due to independent rounding.

e. Includes FY 1994 carry-over, Management Reserve, Contract Close-out and estimated fees. 
INTENTIONALLY LEFT BLANK 


\section{APPENDIX B}

PROGRAM SCHEDULE BASELINE -

YUCCA MOUNTAIN SITE CHARACTERIZATION PROJECT MILESTONES

Revision 5 
INTENTIONALLY LEFT BLANK

Revision 5 
WBS: Waste Package and Repository

\begin{tabular}{lcccc}
$\begin{array}{l}\text { Milestone } \\
\text { Number }\end{array}$ & Baseline Date & WBS & $\begin{array}{c}\text { Responsible RW } \\
\text { Organization }\end{array}$ & Highest CCB \\
\hline R4210 & $9 / 27 / 96$ & $1.2 .2, .1 .2 .4$ & YMSCO & PBCCB
\end{tabular}

Milestone Description

Complete MGDS to TSS/EIS Conceptual Design/Start Preliminary Design

\section{Milestone Completion Criteria}

This milestone will be complete upon RW-1's acceptance of an integrated waste package and repository concept that meets the technical baseline requirements. Additionally, the Director of OCRWM approves the start of the MGDS preliminary design.

\begin{tabular}{lcccc}
$\begin{array}{l}\text { Milestone } \\
\text { Number }\end{array}$ & Baseline Date & WBS & $\begin{array}{c}\text { Responsible RW } \\
\text { Organization }\end{array}$ & $\begin{array}{c}\text { Highest } \\
\text { CCB }\end{array}$ \\
\hline R4220 & $9 / 29 / 00$ & $1.2 .2,1.2 .4$ & YMSCO & PBCCB
\end{tabular}

\section{Milestone Description}

Complete MGDS Preliminary Design/Start MGDS Final Design

\section{Milestone Completion Criteria}

This milestone will be complete upon RW-1's acceptance of the MGDS preliminary design that meets the technical baseline requirements and provides input into the License Application and Safety Analysis Report. Additionally, the Director of OCRWM approves the start of the MGDS final design for construction. 


\section{WBS: Regulatory}

\begin{tabular}{lcccc}
$\begin{array}{l}\text { Milestone } \\
\text { Number }\end{array}$ & Baseline Date & WBS & $\begin{array}{c}\text { Responsible RW } \\
\text { Organization }\end{array}$ & $\begin{array}{c}\text { Highest } \\
\text { CCB }\end{array}$ \\
\hline R5226 & $9 / 29 / 95$ & 1.2 .5 & YMSCO & PBCCB
\end{tabular}

\section{Milestone Description}

Issue HLF Decision - Surface Processes

\section{Milestone Completion Criteria}

This milestone will be complete when RW-1 makes a final determination based primarily on the technical basis and regulatory compliance assessment on erosion, surface characteristics, and hydrology. RW-1 issues the determination of the higher level finding in a Federal Register Notice.

\section{Milestone Description}

Issue HLF Decision - Seismic/Tectonics/Volcanism

\section{Milestone Completion Criteria}

This milestone will be complete when RW-1 makes a final determination based primarily on the technical basis and regulatory compliance assessment on seismic characteristics, tectonics, and volcanism. RW-1 issues the determination of the higher level finding in a Federal Register Notice. 


\begin{tabular}{lcccc}
$\begin{array}{l}\text { Milestone } \\
\text { Number }\end{array}$ & Baseline Date & WBS & $\begin{array}{c}\text { Responsible RW } \\
\text { Organization }\end{array}$ & $\begin{array}{c}\text { Highest } \\
\text { CCB }\end{array}$ \\
\hline R5233 & $2 / 28 / 97$ & 1.2 .5 & YMSCO & PBCCB
\end{tabular}

\section{Milestone Description}

Issue HLF Decision - Preclosure Radiological Safety

\section{Milestone Completion Criteria}

This milestone will be complete when RW-1 makes a final determination based primarily on the technical basis and regulatory compliance assessment on preclosure radiological safety. RW-1 issues the determination of the higher level finding in a Federal Register Notice.

\begin{tabular}{lcccc}
$\begin{array}{l}\text { Milestone } \\
\text { Number }\end{array}$ & Baseline Date & WBS & $\begin{array}{c}\text { Responsible RW } \\
\text { Organization }\end{array}$ & $\begin{array}{c}\text { Highest } \\
\text { CCB }\end{array}$ \\
\hline R5231 & $7 / 31 / 97$ & 1.2 .5 & YMSCO & PBCCB
\end{tabular}

\section{Milestone Description}

Issue HLF Decision - Geochemistry/Rock Characteristics

\section{Milestone Completion Criteria}

This milestone will be complete when RW-1 makes a final determination based primarily on the technical basis and regulatory compliance assessment on geochemistry, rock characteristics, and human intrusion. RW-1 issues the determination of the higher level finding in a Federal Register Notice. 


\begin{tabular}{lcccc}
$\begin{array}{l}\text { Milestone } \\
\text { Number }\end{array}$ & Baseline Date & WBS & $\begin{array}{c}\text { Responsible RW } \\
\text { Organization }\end{array}$ & $\begin{array}{c}\text { Highest } \\
\text { CCB }\end{array}$ \\
\hline R5232 & $7 / 31 / 97$ & 1.2 .5 & YMSCO & PBCCB
\end{tabular}

\section{Milestone Description}

Issue HLF Decision - Reasonably Available Technology

\section{Milestone Completion Criteria}

This milestone will be complete when RW-1 makes a final determination based primarily on the regulatory compliance assessment of the qualifying condition for the preclosure system guideline concerning ease and cost of siting, construction, operation, and closure. This assessment will combine the results of guideline compliance assessments for the supporting preclosure technical guidelines for surface characteristics, rock characteristics, tectonics, and hydrology. RW-1 issues the determination of the higher level finding in a Federal Register Notice.

\section{Milestone Description}

Issue HLF Decision - Geohydrology/Transport

\section{Milestone Completion Criteria}

This milestone will be complete when RW-1 makes a final determination based primarily on the technical basis and regulatory compliance assessment on geohydrology and transport characteristics. RW-1 issues the determination of the higher level finding in a Federal Register Notice. 


\begin{tabular}{lcccc}
$\begin{array}{l}\text { Milestone } \\
\text { Number }\end{array}$ & Baseline Date & WBS & $\begin{array}{c}\text { Responsible RW } \\
\text { Organization }\end{array}$ & $\begin{array}{c}\text { Highest } \\
\text { CCB }\end{array}$ \\
\hline R5240 & $9 / 29 / 95$ & 1.2 .5 & YMSCO & PBCCB
\end{tabular}

\section{Milestone Description}

Issue HLF Decision - Total System Performance

\section{Milestone Completion Criteria}

This milestone will be complete when RW-1 makes a final determination based primarily on the technical basis and regulatory compliance assessment on the total system performance assessment system guideline and the postclosure technical guidelines. RW-1 issues the determination of the higher level finding in a Eederal Register Notice.

\begin{tabular}{lcccc}
$\begin{array}{l}\text { Milestone } \\
\text { Number }\end{array}$ & Baseline Date & WBS & $\begin{array}{c}\text { Responsible RW } \\
\text { Organization }\end{array}$ & $\begin{array}{c}\text { Highest } \\
\text { CCB }\end{array}$ \\
\hline R5236 & $9 / 30 / 95$ & 1.2 .5 & YMSCO & PBCCB
\end{tabular}

\section{Milestone Description}

Issue Decision on Technical Site Suitability

\section{Milestone Completion Criteria}

This milestone will be complete when the Director of OCRWM has completed the assessment of the suitability of the Yucca Mountain site, for development as a repository, in accordance with the technical guidelines of 10 CFR 960. The Director's findings will be documented in a technical site suitability evaluation report and transmitted by letter to the Secretary of Energy. 


\begin{tabular}{lcccc}
$\begin{array}{l}\text { Milestone } \\
\text { Number }\end{array}$ & Baseline Date & WBS & $\begin{array}{c}\text { Responsible RW } \\
\text { Organization }\end{array}$ & $\begin{array}{c}\text { Highest } \\
\text { CCB }\end{array}$ \\
\hline R5250 & $5 / 26 / 99$ & 1.2 .5 & YMSCO & PBCCB
\end{tabular}

\section{Milestone Description}

Issue HLF Decision - Environmental Quality, Socioeconomic, Transportation

\section{Milestone Completion Criteria}

This milestone will be complete when RW-1 makes a final determination based primarily on the technical basis and regulatory compliance assessment on environmental quality, socioeconomics, and transportation. RW-1 issues the determination of the higher level finding in a Federal Register Notice.

\begin{tabular}{lcccc}
\hline $\begin{array}{l}\text { Milestone } \\
\text { Number }\end{array}$ & Baseline Date & WBS & $\begin{array}{c}\text { Responsible RW } \\
\text { Organization }\end{array}$ & $\begin{array}{c}\text { Highest } \\
\text { CCB }\end{array}$ \\
\hline R5260 & $8 / 14 / 00$ & 1.2 .5 & YMSCO & PBCCB
\end{tabular}

\section{Milestone Description}

Submit Draft State Notification of Site Selection

\section{Milestone Completion Criteria}

This milestone will be complete when the Director of OCRWM submits to the Secretary of Energy a draft of the notification of site selection required by Section 114(a)(1) of the NWPA, as amended. 


\begin{tabular}{lcccc}
$\begin{array}{l}\text { Milestone } \\
\text { Number }\end{array}$ & Baseline Date & WBS & $\begin{array}{c}\text { Responsible RW } \\
\text { Organization }\end{array}$ & $\begin{array}{c}\text { Highest } \\
\text { CCB }\end{array}$ \\
\hline R5220 & $8 / 28 / 00$ & 1.2 .5 & YMSCO & ESAAB
\end{tabular}

\section{Milestone Description}

Notify State of Site Selection

\section{Milestone Completion Criteria}

This milestone will be complete when the Secretary of Energy makes notification of site selection required by Section 114(a)(1) of the NWPA, as amended.

\begin{tabular}{lcccc}
$\begin{array}{l}\text { Milestone } \\
\text { Number }\end{array}$ & Baseline Date & WBS & $\begin{array}{c}\text { Responsible RW } \\
\text { Organization }\end{array}$ & $\begin{array}{c}\text { Highest } \\
\text { CCB }\end{array}$ \\
\hline R5210 & $9 / 15 / 00$ & 1.2 .5 & YMSCO & PBCCB
\end{tabular}

\section{Milestone Description \\ Issue SRR to Secretary of Energy}

\section{Milestone Completion Criteria}

This milestone will be complete when the Director of OCRWM submits the Site Recommendation Report to the Secretary of Energy. The Director certifies the Site Recommendation Report contains all the information specified in the Nuclear Waste Policy Act, Section 114(a)(1), Subparagraphs a-g, which includes the Environmental Impact Statement. 


\begin{tabular}{lcccc}
$\begin{array}{l}\text { Milestone } \\
\text { Number }\end{array}$ & Baseline Date & WBS & $\begin{array}{c}\text { Responsible RW } \\
\text { Organization }\end{array}$ & $\begin{array}{c}\text { Highest } \\
\text { CCB }\end{array}$ \\
\hline R5200 & $9 / 29 / 00$ & 1.2 .5 & YMSCO & ESAAB
\end{tabular}

\section{Milestone Description}

Issue Site Recommendation Report to President

\section{Milestone Completion Criteria}

This milestone will be complete when the Secretary of Energy submits the site recommendation report to the President. The report will provide a comprehensive statement of the basis for site recommendation, including the FEIS and the other information identified in Section $114(\mathrm{a})(\mathrm{l})(\mathrm{a}-\mathrm{g})$ of the Nuclear Waste Policy Act (NWPA).

\begin{tabular}{lcccc}
$\begin{array}{l}\text { Milestone } \\
\text { Number }\end{array}$ & Baseline Date & WBS & $\begin{array}{c}\text { Responsible RW } \\
\text { Organization }\end{array}$ & $\begin{array}{c}\text { Highest } \\
\text { CCB }\end{array}$ \\
\hline R5280 & $6 / 15 / 01$ & 1.2 .5 & YMSCO & PBCCB
\end{tabular}

\section{Milestone Description}

Concur on Final License Application

\section{Milestone Completion Criteria}

This milestone will be complete when the Director of OCRWM certifies that a camera-ready version of the License Application is ready for submittal to the NRC. That certification additionally states compliance with the LA information requirements of 10 CFR 60 , and that appropriate land has been withdrawn from the public domain for DOE use. 


\begin{tabular}{lcccc}
$\begin{array}{l}\text { Milestone } \\
\text { Number }\end{array}$ & Baseline Date & WBS & $\begin{array}{c}\text { Responsible RW } \\
\text { Organization }\end{array}$ & $\begin{array}{c}\text { Highest } \\
\text { CCB }\end{array}$ \\
\hline R5181 & $6 / 29 / 01$ & 1.2 .5 & YMSCO & ESAAB
\end{tabular}

\section{Milestone Description}

Submit License Application to the NRC

\section{Milestone Completion Criteria}

This milestone will be complete when the LA is approved by the Secretary of Energy and submitted to the NRC in accordance with 10 CFR 60.22, requesting permission to start repository construction. Prerequisites include License Application Design Review (LADR).

\section{Milestone Description}

Turnover LSS to NRC

\section{Milestone Completion Criteria}

This milestone will be complete upon the successful completion of an LSS acceptance test conducted by YMSCO and the LSS administrator. 
WBS: Environmental, Safety and Health

\begin{tabular}{lcccc}
$\begin{array}{l}\text { Milestone } \\
\text { Number }\end{array}$ & Baseline Date & WBS & $\begin{array}{c}\text { Responsible RW } \\
\text { Organization }\end{array}$ & $\begin{array}{c}\text { Highest } \\
\text { CCB }\end{array}$ \\
\hline R5141 & $5 / 31 / 95$ & 1.2 .13 & YMSCO & PBCCB
\end{tabular}

\title{
Milestone Description
}

Publish EIS Notice of Intent (NOI).

\section{Milestone Completion Criteria}

This milestone will be complete when the EIS Notice of Intent is published in the Federal Register. That notice announces the DOE intent to initiate development of an EIS for a potential repository at Yucca Mountain. The NOI initiates the scoping process for the DEIS.

\begin{tabular}{lcccc}
\hline $\begin{array}{l}\text { Milestone } \\
\text { Number }\end{array}$ & Baseline Date & WBS & $\begin{array}{c}\text { Responsible RW } \\
\text { Organization }\end{array}$ & $\begin{array}{c}\text { Highest } \\
\text { CCB }\end{array}$ \\
\hline R5151 & $9 / 28 / 98$ & 1.2 .13 & YMSCO & PBCCB
\end{tabular}

\author{
Milestone Description \\ Issue Draft Environmental Impact Statement
}

\section{Milestone Completion Criteria}

This milestone will be complete when the DEIS is published and disseminated for public review and comment. 


\begin{tabular}{lcccc}
$\begin{array}{l}\text { Milestone } \\
\text { Number }\end{array}$ & Baseline Date & WBS & $\begin{array}{c}\text { Responsible RW } \\
\text { Organization }\end{array}$ & $\begin{array}{c}\text { Highest } \\
\text { CCB }\end{array}$ \\
\hline R5153 & $8 / 25 / 00$ & 1.2 .13 & YMSCO & PBCCB
\end{tabular}

\section{Milestone Description}

File FEIS with EPA

\section{Milestone Completion Criteria}

After preparation of the preliminary Final Environmental Impact Statement (FEIS), and on the basis of the Department of Energy's internal review and the Secretary's approval, the FEIS will be filed with the U.S. Environmental Protection Agency.

\begin{tabular}{lcccc}
$\begin{array}{l}\text { Milestone } \\
\text { Number }\end{array}$ & Baseline Date & WBS & $\begin{array}{c}\text { Responsible RW } \\
\text { Organization }\end{array}$ & $\begin{array}{c}\text { Highest } \\
\text { CCB }\end{array}$ \\
\hline R5155 & $8 / 25 / 00$ & 1.2 .13 & YMSCO & PBCCB
\end{tabular}

\section{Milestone Description}

Issue Final EIS - Including Comment Response Document

\section{Milestone Completion Criteria}

After preparation of the preliminary Final Environmental Impact Statement (FEIS), and on the basis of the Department of Energy's internal review and the Secretary's approval, the FEIS will be filed with the U.S. Environmental Protection Agency. The FEIS and Comment Response Document will be issued, incorporating internal comments on the preliminary FEIS. 


\begin{tabular}{lcccc}
$\begin{array}{l}\text { Milestone } \\
\text { Number }\end{array}$ & Baseline Date & WBS & $\begin{array}{c}\text { Responsible RW } \\
\text { Organization }\end{array}$ & $\begin{array}{c}\text { Highest } \\
\text { CCB }\end{array}$ \\
\hline R5161 & $8 / 25 / 00$ & 1.2 .13 & YMSCO & PBCCB
\end{tabular}

\section{Milestone Description}

Issue Notice of FEIS Availability

\section{Milestone Completion Criteria}

This milestone will be complete when notice of the FEIS availability is published in the Federal Register, upon which a 30-day waiting period must elapse before the Department of Energy can make a decision on the action examined in the EIS. Copies of the FEIS will be distributed to all interested parties.

\begin{tabular}{lcccc}
$\begin{array}{l}\text { Milestone } \\
\text { Number }\end{array}$ & Baseline Date & WBS & $\begin{array}{c}\text { Responsible RW } \\
\text { Organization }\end{array}$ & $\begin{array}{c}\text { Highest } \\
\text { CCB }\end{array}$ \\
\hline R5171 & $9 / 22 / 00$ & 1.2 .13 & YMSCO & ESAAB
\end{tabular}

\section{Milestone Description}

Approve Repository Final Record of Decision

\section{Milestone Completion Criteria}

After the 30-day waiting period following publication in the Federal Register of the Notice of Availability of the final Environmental Impact Statement, the Department of Energy will publish a Record of Decision in the Federal Register describing the final decision on the repository and any determination regarding a waste transportation corridor in Nevada. 


\section{APPENDLX C}

ANNUALIZED COST BASELINE FOR THE

WASTE ACCEPTANCE, STORAGE AND TRANSPORTATION PROJECT (WAST)

Revision 5 
INTENTIONALLY LEFT BLANK

Revision 5 
ANNUALIZED COST BASELINE - WASTE ACCEPTANCE, STORAGE AND TRANSPORTATION PROJECT (WAST)

(Millions of year-of-expenditure dollars)

\begin{tabular}{|c|c|c|c|c|c|c|c|c|}
\hline WBS Element & $\begin{array}{l}\text { Pre } \\
\text { FY1995 }\end{array}$ & FY1995 & FY1996 & FY1997 & FY1998 & FY1999 & FY2000 & TOTAL \\
\hline Spent Fuel Storage & & 4.2 & 4.1 & 3.1 & 3.1 & 3.1 & 3.1 & 20.7 \\
\hline Transportation & & 14.8 & 15.2 & 10.3 & 14.3 & 16.3 & 18.3 & 89.0 \\
\hline Waste Acceptance & & 5.8 & 8.3 & 13.4 & 14.1 & 10.5 & 8.8 & 60.8 \\
\hline MPC Subsystem & & 14.4 & 30.4 & 33.5 & 37.5 & 48.1 & 62.8 & 226.7 \\
\hline WAST PM\&I & & 3.6 & 6.9 & 6 & 6.2 & 5.3 & 5.0 & 33.2 \\
\hline Other & & 3.6 & & & & & & 3.6 \\
\hline TOTAL & 317.5 & 46.3 & 64.9 & 66.4 & 75.2 & 83.2 & 98.0 & 751.5 \\
\hline
\end{tabular}

Notes:

1. Cost History (FY83-94) -- source is OCRWM Monthly Report on Program Status as of June 1995.

2. Funding for FY96-00 is current estimate for the Program Approach, including the Technical Support Contractor. The FY96 through FY00 projected costs are consistent with the RW-35 memo dated March 30, 1995 that provided guidance for the FY97 IRB budget development, expressed as estimated annual expenditures rather than New Budget Authority.

3. FY95 budget is the PACS Performance Measurement Baseline (PMB) latest revised estimate as of June 30, 1995, plus contract close-out and estimated fees (identified as other). 
INTENTIONALLY LEFT BLANK

C-2

Revision 5 


\section{APPENDIX D}

PROGRAM SCHEDULE BASELINE -

WAST PROJECT MLESTONES

Revision 5 
INTENTIONALLY LEFT BLANK

Revision 5 


\begin{tabular}{lcccc}
$\begin{array}{l}\text { Milestone } \\
\text { Number }\end{array}$ & Baseline Date & WBS & $\begin{array}{c}\text { Responsible RW } \\
\text { Organization }\end{array}$ & $\begin{array}{c}\text { Highest } \\
\text { BCCB }\end{array}$ \\
\hline T1299A & $7 / 31 / 98$ & 3.2 .2 & 46 & PBCCB
\end{tabular}

\section{Milestone Description}

Receive CoC for GA-9 LWT cask from the NRC

\section{Milestone Completion Criteria}

This milestone will be complete when the Department receives $\mathrm{CoC}(\mathrm{s})$ for the GA-9 Casks from the NRC.

\begin{tabular}{lcccc}
\hline $\begin{array}{l}\text { Milestone } \\
\text { Number }\end{array}$ & Baseline Date & WBS & $\begin{array}{c}\text { Responsible RW } \\
\text { Organization }\end{array}$ & $\begin{array}{c}\text { Highest } \\
\text { BCCB }\end{array}$ \\
\hline T1299 & $6 / 30 / 97$ & 3.2 .2 & 46 & PBCCB
\end{tabular}

\section{Milestone Description}

Receive CoC for GA-4 LWT cask from the NRC (without BU credit)

\section{Milestone Completion Criteria}

This milestone will be complete when the Department receives $\mathrm{CoC}(\mathrm{s})$ for the GA-4 Casks from the NRC. 


\begin{tabular}{lcccc}
$\begin{array}{l}\text { Milestone } \\
\text { Number }\end{array}$ & Baseline Date & WBS & $\begin{array}{c}\text { Responsible RW } \\
\text { Organization }\end{array}$ & $\begin{array}{c}\text { Highest } \\
\text { BCCB }\end{array}$ \\
\hline $\mathrm{T} 1250 \mathrm{E}$ & $10 / 30 / 97$ & 3.2 .2 & 46 & PBCCB
\end{tabular}

\section{Milestone Description}

Receive Draft Part 71 (Transportation Cask) SER from the NRC

\section{Milestone Completion Criteria}

This milestone will be complete when the Department receives a draft SER from the NRC for the MPC transportation cask(s).

\begin{tabular}{lcccc}
\hline $\begin{array}{l}\text { Milestone } \\
\text { Number }\end{array}$ & Baseline Date & WBS & $\begin{array}{c}\text { Responsible RW } \\
\text { Organization }\end{array}$ & $\begin{array}{c}\text { Highest } \\
\text { BCCB }\end{array}$ \\
\hline T1250 & $10 / 30 / 98$ & 3.2 .2 & 46 & PBCCB
\end{tabular}

\section{Milestone Description}

Receive MPC Part 71 (Transportation Cask) CoC and Final SER from the NRC

\section{Milestone Completion Criteria}

This milestone will be complete when the NRC issues CoC(s) for the MPC Transportation Cask(s). 


\begin{tabular}{lcccc}
$\begin{array}{l}\text { Milestone } \\
\text { Number }\end{array}$ & Baseline Date & WBS & $\begin{array}{c}\text { Responsible RW } \\
\text { Organization }\end{array}$ & $\begin{array}{c}\text { Highest } \\
\text { BCCB }\end{array}$ \\
\hline T255 & $1 / 3 / 95$ & 3.2 .5 & 45 & PBCCB
\end{tabular}

\section{Milestone Description}

Issue Notice of Inquiry on NWPA 180(c) Administrative Process

\section{Milestone Completion Criteria}

This milestone was completed when the Notice of Inquiry responding to NWPA Section 180 (c) requirements for development of proposed policy and procedure was published in the Federal Register.

\begin{tabular}{lcccc}
$\begin{array}{l}\text { Milestone } \\
\text { Number }\end{array}$ & Baseline Date & WBS & $\begin{array}{c}\text { Responsible RW } \\
\text { Organization }\end{array}$ & $\begin{array}{c}\text { Highest } \\
\text { BCCB }\end{array}$ \\
\hline T265 & $3 / 29 / 96$ & 3.2 .5 & 45 & PBCCB
\end{tabular}

\section{Milestone Description}

Publish Notice of Proposed Policy and Procedure for NWPA Section 180(c)

\section{Milestone Completion Criteria}

This milestone will be complete when the Notice of Policy and Procedures for NWPA Section 180 (c) has been published in the Federal Register. 


\begin{tabular}{lcccc}
$\begin{array}{l}\text { Milestone } \\
\text { Number }\end{array}$ & Baseline Date & WBS & $\begin{array}{c}\text { Responsible RW } \\
\text { Organization }\end{array}$ & $\begin{array}{c}\text { Highest } \\
\text { BCCB }\end{array}$ \\
\hline T270 & $6 / 30 / 97$ & 3.2 .5 & 45 & PBCCB
\end{tabular}

\section{Milestone Description}

Publish Final Notice of Policy and Procedures (180(c))

\section{Milestone Completion Criteria}

This milestone will be complete when the final notice of implementing the provisions of NEPA Section 180(c) is published in the Federal Register.

\begin{tabular}{lcccc}
\hline $\begin{array}{l}\text { Milestone } \\
\text { Number }\end{array}$ & Baseline Date & WBS & $\begin{array}{c}\text { Responsible RW } \\
\text { Organization }\end{array}$ & $\begin{array}{c}\text { Highest } \\
\text { BCCB }\end{array}$ \\
\hline W001 & $5 / 25 / 94$ & 3.3 .3 & 44 & PBCCB
\end{tabular}

\section{Milestone Description}

Issue Notice of Inquiry (NOI) on Waste Acceptance Issues

\section{Milestone Completion Criteria}

This milestone was completed when the NOI was issued on May 25, 1994. 


\begin{tabular}{lcccc}
$\begin{array}{l}\text { Milestone } \\
\text { Number }\end{array}$ & Baseline Date & WBS & $\begin{array}{c}\text { Responsible RW } \\
\text { Organization }\end{array}$ & $\begin{array}{c}\text { Highest } \\
\text { BCCB }\end{array}$ \\
\hline W003 & $9 / 5 / 96$ & 3.3 .3 & 44 & PBCCB
\end{tabular}

\section{Milestone Description}

Publish NOPR on Standard Contract (10CFR961) revisions

\section{Milestone Completion Criteria}

This milestone will be complete when the Notice of Proposed Rulemaking on Standard Contract (10CFR961) revisions is published in the Federal Register.

\begin{tabular}{lcccc}
$\begin{array}{l}\text { Milestone } \\
\text { Number }\end{array}$ & Baseline Date & WBS & $\begin{array}{c}\text { Responsible RW } \\
\text { Organization }\end{array}$ & $\begin{array}{c}\text { Highest } \\
\text { BCCB }\end{array}$ \\
\hline W035 & $10 / 2 / 97$ & 3.3 .3 & 44 & PBCCB
\end{tabular}

\section{Milestone Description}

Publish Final Rule on Standard Contract revisions

\section{Milestone Completion Criteria}

This milestone will be complete when the Final Rule on Standard Contract (10CFR961) revisions is published in the Eederal Register. 


\begin{tabular}{lcccc}
$\begin{array}{l}\text { Milestone } \\
\text { Number }\end{array}$ & Baseline Date & WBS & $\begin{array}{c}\text { Responsible RW } \\
\text { Organization }\end{array}$ & $\begin{array}{c}\text { Highest } \\
\text { BCCB }\end{array}$ \\
\hline W030 & $10 / 30 / 97$ & 3.3 .3 & 44 & PBCCB
\end{tabular}

\section{Milestone Description}

Begin SNF Records (Data) verification process at utility sites

\section{Milestone Completion Criteria}

This milestone will be complete when the Department begins on-site verification of the spent nuclear fuel records of the first utility.

\begin{tabular}{lcccc}
$\begin{array}{l}\text { Milestone } \\
\text { Number }\end{array}$ & Baseline Date & WBS & $\begin{array}{c}\text { Responsible RW } \\
\text { Organization }\end{array}$ & $\begin{array}{c}\text { Highest } \\
\text { BCCB }\end{array}$ \\
\hline M4050 & $3 / 1 / 94$ & 3.4 .1 & 46 & ESAAB
\end{tabular}

\section{Milestone Description}

Decide to Proceed with MPC Concept

\section{Milestone Completion Criteria}

This milestone was completed when DOE issued a Technical Direction letter on the MPC decision on February 18, 1994. 


\begin{tabular}{lcccc}
$\begin{array}{l}\text { Milestone } \\
\text { Number }\end{array}$ & Baseline Date & WBS & $\begin{array}{c}\text { Responsible RW } \\
\text { Organization }\end{array}$ & $\begin{array}{c}\text { Highest } \\
\text { BCCB }\end{array}$ \\
\hline M4150 & $6 / 3 / 94$ & 3.4 .1 & 46 & PBCCB
\end{tabular}

Milestone Description

Issue MPC RFP for Design

\section{Milestone Completion Criteria}

This milestone was completed when the Request for Proposal (RFP) for the MPC was issued on June 3, 1994.

\begin{tabular}{lcccc}
$\begin{array}{l}\text { Milestone } \\
\text { Number }\end{array}$ & Baseline Date & WBS & $\begin{array}{c}\text { Responsible RW } \\
\text { Organization }\end{array}$ & $\begin{array}{c}\text { Highest } \\
\text { BCCB }\end{array}$ \\
\hline T060 & $4 / 24 / 96$ & 3.4 .2 & 46 & PBCCB
\end{tabular}

\section{Milestone Description}

Submit MPC Transportation Cask SAR to the NRC

\section{Milestone Completion Criteria}

This milestone will be complete when the MPC Transportation Cask Safety Analysis

Report(s) is submitted to the NRC for 10CFR Part 71 Review. 


\begin{tabular}{lcccc}
$\begin{array}{l}\text { Milestone } \\
\text { Number }\end{array}$ & Baseline Date & WBS & $\begin{array}{c}\text { Responsible RW } \\
\text { Organization }\end{array}$ & $\begin{array}{c}\text { Highest } \\
\text { BCCB }\end{array}$ \\
\hline M602A & $4 / 24 / 96$ & 3.4 .2 & 46 & PBCCB
\end{tabular}

\section{Milestone Description}

Submit MPC Storage Overpack SAR to the NRC

\section{Milestone Completion Criteria}

This milestone will be complete when the MPC On-Site Transfer and Storage subsystem Topical Safety Analysis Report(s) is submitted to the NRC for 10CFR Part 72 review.

\begin{tabular}{lcccc}
$\begin{array}{l}\text { Milestone } \\
\text { Number }\end{array}$ & Baseline Date & WBS & $\begin{array}{c}\text { Responsible RW } \\
\text { Organization }\end{array}$ & $\begin{array}{c}\text { Highest } \\
\text { BCCB }\end{array}$ \\
\hline T1250D & $11 / 28 / 97$ & 3.4 .2 & 46 & PBCCB
\end{tabular}

\section{Milestone Description}

Receive fabrication exemption for the MPCs from the NRC

\section{Milestone Completion Criteria}

This milestone will be complete when the Department receives a letter authorizing the start of MPC fabrication. Based on the NRC Schedule, it is assumed that milestones M604 and T1250E (Draft Part 71 and 72 SERs) would precede this. 


\begin{tabular}{lcccc}
$\begin{array}{l}\text { Milestone } \\
\text { Number }\end{array}$ & Baseline Date & WBS & $\begin{array}{c}\text { Responsible RW } \\
\text { Organization }\end{array}$ & $\begin{array}{c}\text { Highest } \\
\text { BCCB }\end{array}$ \\
\hline MZ040 & $10 / 30 / 97$ & 3.4 .3 & 46 & PBCCB
\end{tabular}

\section{Milestone Description}

Submit request for MPC fabrication and deployment to ESAAB

\section{Milestone Completion Criteria}

This milestone will be complete when the WAST Project Manager submits to ESAAB the request for MPC fabrication and deployment.

\begin{tabular}{lcccc}
$\begin{array}{l}\text { Milestone } \\
\text { Number }\end{array}$ & Baseline Date & WBS & $\begin{array}{c}\text { Responsible RW } \\
\text { Organization }\end{array}$ & $\begin{array}{c}\text { Highest } \\
\text { BCCB }\end{array}$ \\
\hline M504 & $11 / 28 / 97$ & 3.4 .3 & 46 & PBCCB
\end{tabular}

\section{Milestone Description}

Exercise 1998 option (Initial fabrication contract)

\section{Milestone Completion Criteria}

This milestone will be complete when the $\mathrm{M} \& \mathrm{O}$, with the concurrence of $\mathrm{DOE}$, exercises the option for the 1998 increment of MPCs. The KD-3\&4 decision of Milestone MZ005 (Present WAST Project ESAAB) must be completed prior to exercising the options. This combined ESAAB seeks approval to fabricate and deploy MPCs. Additionally, Milestones M2010 (Issue MPC EIS Record of Decision), M604 (Receive Draft MPC Part 72 (Storage) SER from the NRC), T1250E (Receive Draft Part 71 (Transportation Cask) SER from the NRC) and, finally, T1250D (Receive Fabrication Exemption for MPCs from the NRC) must be completed prior to exercising the options. 


\begin{tabular}{lcccc}
$\begin{array}{l}\text { Milestone } \\
\text { Number }\end{array}$ & Baseline Date & WBS & $\begin{array}{c}\text { Responsible RW } \\
\text { Organization }\end{array}$ & $\begin{array}{c}\text { Highest } \\
\text { BCCB }\end{array}$ \\
\hline M4990 & $10 / 30 / 98$ & 3.4 .3 & 46 & PBCCB
\end{tabular}

\section{Milestone Description}

Start MPC Deployment

\section{Milestone Completion Criteria}

This milestone will be complete when deployment of MPCs begins. Prior to deployment, the KD-4 portion of Milestone MZ005 (Present WAST Project ESAAB (KD-3\&4)) must be completed and approval received to deploy MPCs. Additionally, Milestones M605 (Receive Final MPC CoC \& SER-Storage Part 72) and T1250 (Receive Final MPC CoC \& SER-Transportation Part 71) must be completed.

\begin{tabular}{lcccc}
$\begin{array}{l}\text { Milestone } \\
\text { Number }\end{array}$ & Baseline Date & WBS & $\begin{array}{c}\text { Responsible RW } \\
\text { Organization }\end{array}$ & $\begin{array}{c}\text { Highest } \\
\text { BCCB }\end{array}$ \\
\hline M430A & $8 / 30 / 99$ & 3.4 .3 & 46 & PBCCB
\end{tabular}

\section{Milestone Description}

Issue RFP for follow-on fabrication

\section{Milestone Completion Criteria}

This milestone will be complete when the request for proposals soliciting vendors' technical and cost proposals for the follow on (beyond 2 years) increment of MPC production is released. 


\begin{tabular}{lcccc}
$\begin{array}{l}\text { Milestone } \\
\text { Number }\end{array}$ & Baseline Date & WBS & $\begin{array}{c}\text { Responsible RW } \\
\text { Organization }\end{array}$ & $\begin{array}{c}\text { Highest } \\
\text { BCCB }\end{array}$ \\
\hline MZ041 & $12 / 20 / 99$ & 3.4 .3 & 46 & PBCCB
\end{tabular}

\section{Milestone Description}

Submit request for continued MPC fabrication and deployment to ESAAB

\section{Milestone Completion Criteria}

This milestone will be complete when the WAST Project Manager submits to ESAAB the request for MPC fabrication and deployment.

\begin{tabular}{lcccc}
$\begin{array}{l}\text { Milestone } \\
\text { Number }\end{array}$ & Baseline Date & WBS & $\begin{array}{c}\text { Responsible RW } \\
\text { Organization }\end{array}$ & $\begin{array}{c}\text { Highest } \\
\text { BCCB }\end{array}$ \\
\hline MZ042 & $1 / 31 / 00$ & 3.4 .3 & 46 & ESAAB
\end{tabular}

\section{Milestone Description}

Approval by ESAAB to continue MPC fabrication and deployment

\section{Milestone Completion Criteria}

This milestone will be complete when the WAST Project Manager completes a presentation to the ESAAB and obtains approval to continue MPC fabrication and deployment. 


\begin{tabular}{lcccc}
$\begin{array}{l}\text { Milestone } \\
\text { Number }\end{array}$ & Baseline Date & WBS & $\begin{array}{c}\text { Responsible RW } \\
\text { Organization }\end{array}$ & $\begin{array}{c}\text { Highest } \\
\text { BCCB }\end{array}$ \\
\hline M4392 & $9 / 29 / 00$ & 3.4 .3 & 46 & PBCCB
\end{tabular}

\section{Milestone Description}

Complete initial fabrication of MPCs

\section{Milestone Completion Criteria}

This milestone will be complete when the initial fabrication (two year supply) of the canisters is complete.

\begin{tabular}{lcccc}
$\begin{array}{l}\text { Milestone } \\
\text { Number }\end{array}$ & Baseline Date & WBS & $\begin{array}{c}\text { Responsible RW } \\
\text { Organization }\end{array}$ & $\begin{array}{c}\text { Highest } \\
\text { BCCB }\end{array}$ \\
\hline M300 & $10 / 24 / 94$ & 3.4 .5 & 46 & PBCCB
\end{tabular}

\section{Milestone Description}

Issue Notice of Intent (NOI) on MPC Environmental Impact Statement (EIS)

\section{Milestone Completion Criteria}

This milestone was completed when the Notice of Intent was published in the Federal Register on October 25, 1994. 


\begin{tabular}{lcccc}
$\begin{array}{l}\text { Milestone } \\
\text { Number }\end{array}$ & Baseline Date & WBS & $\begin{array}{c}\text { Responsible RW } \\
\text { Organization }\end{array}$ & $\begin{array}{c}\text { Highest } \\
\text { BCCB }\end{array}$ \\
\hline M2003 & $12 / 10 / 95$ & 3.4 .5 & 46 & PBCCB
\end{tabular}

Milestone Description

Issue MPC DEIS

\section{Milestone Completion Criteria}

This milestone will be complete when a Notice of Document Availability is published in the Federal Register.

\begin{tabular}{lcccc}
$\begin{array}{l}\text { Milestone } \\
\text { Number }\end{array}$ & Baseline Date & WBS & $\begin{array}{c}\text { Responsible RW } \\
\text { Organization }\end{array}$ & $\begin{array}{c}\text { Highest } \\
\text { BCCB }\end{array}$ \\
\hline M2009 & $8 / 26 / 96$ & 3.4 .5 & 46 & PBCCB
\end{tabular}

\section{Milestone Description}

Issue MPC FEIS

\section{Milestone Completion Criteria}

This milestone will be complete when a Notice of Document Availability is published in the Federal Register. 


\begin{tabular}{lcccc}
$\begin{array}{l}\text { Milestone } \\
\text { Number }\end{array}$ & Baseline Date & WBS & $\begin{array}{c}\text { Responsible RW } \\
\text { Organization }\end{array}$ & $\begin{array}{c}\text { Highest } \\
\text { BCCB }\end{array}$ \\
\hline M2010 & $9 / 26 / 96$ & 3.4 .5 & 46 & ESAAB
\end{tabular}

\section{Milestone Description}

Issue MPC EIS Record of Decision

\section{Milestone Completion Criteria}

The milestone will be complete when the Record of Decision is published in the Federal Register.

\section{Milestone Description}

Submit the MPC Part 60 Design Considerations Report to the NRC

\section{Milestone Completion Criteria}

This milestone will be complete when the Department submits the Part 60 Design Considerations Technical Report soliciting a letter of "no objection" to proceed with development of the MPC disposal overpack for use at the repository to the NRC. 


\begin{tabular}{lcccc}
$\begin{array}{l}\text { Milestone } \\
\text { Number }\end{array}$ & Baseline Date & WBS & $\begin{array}{c}\text { Responsible RW } \\
\text { Organization }\end{array}$ & $\begin{array}{c}\text { Highest } \\
\text { BCCB }\end{array}$ \\
\hline M608 & $8 / 31 / 96$ & 3.4 .6 & 46 & PBCCB
\end{tabular}

\section{Milestone Description}

Receive PWR Actinide Burnup credit SER from the NRC

\section{Milestone Completion Criteria}

This milestone will be complete when the NRC approves the Topical Report on PWR Actinide burnup credit (storage and transportation) and its impact on criticality control and the Department receives the SER.

Milestone

Number

M608B
Baseline Date

$5 / 31 / 97$
WBS

3.4 .6
Responsible RW

Organization

46
Highest

BCCB

PBCCB

\section{Milestone Description}

Submit Topical Report on PWR Principal Isotopes to the NRC

\section{Milestone Completion Criteria}

This milestone will be complete when the Department submits the Topical Report on Principal Isotopes burnup credit (storage and transportation) and its impact on criticality control to the NRC. 


\begin{tabular}{lcccc}
$\begin{array}{l}\text { Milestone } \\
\text { Number }\end{array}$ & Baseline Date & WBS & $\begin{array}{c}\text { Responsible RW } \\
\text { Organization }\end{array}$ & $\begin{array}{c}\text { Highest } \\
\text { BCCB }\end{array}$ \\
\hline T280 & $10 / 30 / 97$ & 3.4 .6 & 46 & PBCCB
\end{tabular}

\section{Milestone Description}

Receive "letter of no objection" for use of MPCs in disposal from the NRC

\section{Milestone Completion Criteria}

This milestone will be complete when the NRC finishes its review of the Part 60 Design Considerations Technical Report (submitted as T275) and issues a "letter of no objection" to proceed with development of the MPC disposal overpack for use at the repository.

\begin{tabular}{lcccc}
\hline $\begin{array}{l}\text { Milestone } \\
\text { Number }\end{array}$ & Baseline Date & WBS & $\begin{array}{c}\text { Responsible RW } \\
\text { Organization }\end{array}$ & $\begin{array}{c}\text { Highest } \\
\text { BCCB }\end{array}$ \\
\hline M604 & $10 / 30 / 97$ & 3.4 .6 & 46 & PBCCB
\end{tabular}

\section{Milestone Description}

Receive draft MPC Part 72 (storage) SER from the NRC

\section{Milestone Completion Criteria}

This milestone will be complete when the Department receives a Safety Evaluation Report (SER) for the MPC On-Site Transfer and Storage Segment and a Draft Certificate of Compliance $(\mathrm{CoC})$ from the NRC. 


\begin{tabular}{lcccc}
$\begin{array}{l}\text { Milestone } \\
\text { Number }\end{array}$ & Baseline Date & WBS & $\begin{array}{c}\text { Responsible RW } \\
\text { Organization }\end{array}$ & $\begin{array}{c}\text { Highest } \\
\text { BCCB }\end{array}$ \\
\hline M609D & $8 / 30 / 98$ & 3.4 .6 & 46 & PBCCB
\end{tabular}

\section{Milestone Description}

Receive PWR Principal Isotope BU credit SER from the NRC

\section{Milestone Completion Criteria}

This milestone will be complete when the NRC approves the Topical Report on PWR Principal Isotope burnup credit (storage and transportation) and its impact on criticality control and the Department receives the SER.

\begin{tabular}{lcccc}
$\begin{array}{l}\text { Milestone } \\
\text { Number }\end{array}$ & Baseline Date & WBS & $\begin{array}{c}\text { Responsible RW } \\
\text { Organization }\end{array}$ & $\begin{array}{c}\text { Highest } \\
\text { BCCB }\end{array}$ \\
\hline M605 & $10 / 30 / 98$ & 3.4 .6 & 46 & PBCCB
\end{tabular}

\section{Milestone Description}

Receive MPC Part 72 (Storage) CoC and final SER from the NRC

\section{Milestone Completion Criteria}

This milestone will be complete when the Department receives a Final Certificate of Compliance for the MPC On-Site Transfer and Storage Segment from the NRC. 


\begin{tabular}{lcccc}
$\begin{array}{l}\text { Milestone } \\
\text { Number }\end{array}$ & Baseline Date & WBS & $\begin{array}{c}\text { Responsible RW } \\
\text { Organization }\end{array}$ & $\begin{array}{c}\text { Highest } \\
\text { BCCB }\end{array}$ \\
\hline MZ001 & $4 / 15 / 94$ & 3.5 .1 & 40 & ESAAB
\end{tabular}

Milestone Description

Present WAST Project ESAR \#1

\section{Milestone Completion Criteria}

This milestone was completed when the WAST Project Manager received approval/concurrence of the April 15, 1994 Energy System Acquisition Review presentation to the ESAAB.

\section{Milestone Description}

Present WAST Project ESAR \#2

\section{Milestone Completion Criteria}

This milestone was completed when the WAST Project Manager presented the annual Energy System Acquisition Review presentation to the ESAAB. 


\begin{tabular}{lcccc}
$\begin{array}{l}\text { Milestone } \\
\text { Number }\end{array}$ & Baseline Date & WBS & $\begin{array}{c}\text { Responsible RW } \\
\text { Organization }\end{array}$ & $\begin{array}{c}\text { Highest } \\
\text { BCCB }\end{array}$ \\
\hline MZ030 & $5 / 1 / 95$ & 3.5 .1 & 40 & PBCCB
\end{tabular}

\section{Milestone Description}

Submit Rev. 0 WAST Project Plan to PBCCB

\section{Milestone Completion Criteria}

This milestone was completed when RW-40 submitted the WAST Project Plan to the PBCCB.

\begin{tabular}{lcccc}
$\begin{array}{l}\text { Milestone } \\
\text { Number }\end{array}$ & Baseline Date & WBS & $\begin{array}{c}\text { Responsible RW } \\
\text { Organization }\end{array}$ & $\begin{array}{c}\text { Highest } \\
\text { BCCB }\end{array}$ \\
\hline MZ005 & $11 / 17 / 97$ & 3.5 .1 & 40 & ESAAB
\end{tabular}

\section{Milestone Description}

Decision by ESAAB on MPC Fabrication \& Deployment

\section{Milestone Completion Criteria}

This milestone will be complete when the WAST Project Manager completes a combined $\mathrm{KD}-3 \& 4$ presentation to the ESAAB and obtains approval to award the MPC fabrication contract (Milestone M504) and to start MPC deployment (Milestone M4990). Milestone T280 (Receive "letter of no objection") must be completed prior to this. Milestones M604, \& T1250E (Draft Part 71 and 72 SERs) and milestone T1250D (NRC fabrication exemption) are also required for approval to fabricate. 


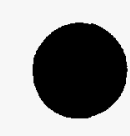

INTENTIONALLY LEFT BLANK 
APPENDIX E

ANNUALIZED COST BASELINE FOR PROGRAM INTEGRATION

Revision 5 
INTENTIONALLY LEFT BLANK

Revision 5 


\section{INTERIM COST BASELINE - PROGRAM INTEGRATION ELEMENT}

(Millions of year-of-expenditure dollars)

\begin{tabular}{|c|c|c|c|c|c|c|c|c|c|}
\hline WBS Element & $\begin{array}{r}\text { FY } 1994 \\
\& \text { Prior }\end{array}$ & FY1995 & FY1996 & FY1997 & FY1998 & FY1999 & FY2000 & FY2001 & TOTAL \\
\hline Quality Assurance & 32 & 15 & 25 & 25 & 26 & 28 & 29 & 29 & 209 \\
\hline $\begin{array}{l}\text { Program Management \& } \\
\text { Integration }\end{array}$ & 637 & 70 & 54 & 58 & 60 & 65 & 73 & 76 & 1093 \\
\hline $\begin{array}{l}\text { Human Resources \& } \\
\text { Administration }\end{array}$ & 83 & 32 & 25 & 25 & 25 & 26 & 26 & 27 & 269 \\
\hline TOTAL $^{(a)}$ & 752 & 117 & 103 & 108 & 112 & 119 & 129 & 132 & 1,571 \\
\hline
\end{tabular}

a. May not add to sum of lower level WBS elements due to rounding. 


\section{INTENTIONALLY LEFT BLANK}




\section{APPENDIX F}

PROGRAM SCHEDULE BASELINE PROGRAM INTEGRATION MLESTONES

Revision 5 
INTENTIONALLY LEFT BLANK

Revision 5 


\section{WBS: Program Management \& Integration}

\begin{tabular}{lcccc}
$\begin{array}{l}\text { Milestone } \\
\text { Number }\end{array}$ & Baseline Date & WBS & $\begin{array}{c}\text { Responsible RW } \\
\text { Organization }\end{array}$ & $\begin{array}{c}\text { Highest } \\
\text { BCCB }\end{array}$ \\
\hline P6000 & $1 / 15 / 96$ & 9.2 & 30 & ESAAB
\end{tabular}

Milestone Description

Approve ESAAB Program Approach Baseline

\section{Milestone Completion Criteria}

This milestone will be complete when the Program Approach baseline is approved by the ESAAB. Prerequisites include approval of the Program Approach baseline by the Program Director, supported by the Strategic System Program Execution Plan, the technical baseline suite to implement the Program Approach, the Program Cost and Schedule Baseline, and the Program

\begin{tabular}{lcccc}
$\begin{array}{l}\text { Milestone } \\
\text { Number }\end{array}$ & Baseline Date & WBS & $\begin{array}{c}\text { Responsible RW } \\
\text { Organization }\end{array}$ & $\begin{array}{c}\text { Highest } \\
\text { BCCB }\end{array}$ \\
\hline PA660 & Annual: Sep & 9.2 & 30 & PBCCB
\end{tabular}

\section{Milestone Description}

Approve OMB Budget Request

\section{Milestone Completion Criteria}

This annual milestone will be complete when the Office of Management and Budget budget request for OCRWM is approved by the Program Director for the transmittal to the DOE Chief Financial Officer. This submission will satisfy DOE and OMB requirements. Prerequisites include issuance of OMB budget request development guidance and Project and Office completion of their respective sections. 


\begin{tabular}{lcccc}
$\begin{array}{l}\text { Milestone } \\
\text { Number }\end{array}$ & Baseline Date & WBS & $\begin{array}{c}\text { Responsible RW } \\
\text { Organization }\end{array}$ & $\begin{array}{c}\text { Highest } \\
\text { BCCB }\end{array}$ \\
\hline PA670 & Annual: Sep & 9.2 & 30 & PBCCB
\end{tabular}

\section{Milestone Description}

Approve Fee Adequacy Report

\section{Milestone Completion Criteria}

This annual milestone will be complete when the fee adequacy report is approved by the Program Director for release. Prerequisite to this report is the adequacy analysis based on the TSLCC analysis and report.

\begin{tabular}{lcccc}
$\begin{array}{l}\text { Milestone } \\
\text { Number }\end{array}$ & Baseline Date & WBS & $\begin{array}{c}\text { Responsible RW } \\
\text { Organization }\end{array}$ & $\begin{array}{c}\text { Highest } \\
\text { BCCB }\end{array}$ \\
\hline PA610 & Annual: Oct & 9.2 & 30 & PBCCB
\end{tabular}

\section{Milestone Description}

Approve Program Plan

\section{Milestone Completion Criteria}

This milestone will be complete when the Program Plan is approved by the Program Director for release. Prerequisite to this submission is development of portions by the Yucca Mountain Site Characterization Office and by the Office of Waste Acceptance, Storage and Transportation consistent with the Program policy and baseline. 


\begin{tabular}{lcccc}
$\begin{array}{l}\text { Milestone } \\
\text { Number }\end{array}$ & Baseline Date & WBS & $\begin{array}{c}\text { Responsible RW } \\
\text { Organization }\end{array}$ & $\begin{array}{c}\text { Highest } \\
\text { BCCB }\end{array}$ \\
\hline P5000 & $9 / 19 / 95$ & 9.2 & 30 & PBCCB
\end{tabular}

\section{Milestone Description}

Approve Program Approach Baseline

\section{Milestone Completion Criteria}

This milestone was completed when the Program Approach baseline was approved by the Program Director. Prerequisites included Program approval of the technical baseline change to implement the Program Approach, the Program Cost and Schedule Baseline, and the Program WBS Dictionary.

\begin{tabular}{lcccc}
$\begin{array}{l}\text { Milestone } \\
\text { Number }\end{array}$ & Baseline Date & WBS & $\begin{array}{c}\text { Responsible RW } \\
\text { Organization }\end{array}$ & $\begin{array}{c}\text { Highest } \\
\text { BCCB }\end{array}$ \\
\hline PA630 & Annual: Feb & 9.2 & 30 & PBCCB
\end{tabular}

\section{Milestone Description}

Approve Interim TSLCC Analysis Update

\section{Milestone Completion Criteria}

This milestone will be complete when the interim TSLCC analysis update is approved by the Program Director to support Congressional testimony. Prerequisites include approval of Program TSLCC assumptions and interim life cycle cost estimates. 


\begin{tabular}{lcccc}
$\begin{array}{l}\text { Milestone } \\
\text { Number }\end{array}$ & Baseline Date & WBS & $\begin{array}{c}\text { Responsible RW } \\
\text { Organization }\end{array}$ & $\begin{array}{c}\text { Highest } \\
\text { BCCB }\end{array}$ \\
\hline PA650 & Annual: Jun & 9.2 & 30 & PBCCB
\end{tabular}

\section{Milestone Description}

Approve Final TSLCC Report

\section{Milestone Completion Criteria}

This annual milestone will be complete when the Program Director approves the TSLCC report for release.

\begin{tabular}{lcccc}
$\begin{array}{l}\text { Milestone } \\
\text { Number }\end{array}$ & Baseline Date & WBS & $\begin{array}{c}\text { Responsible RW } \\
\text { Organization }\end{array}$ & $\begin{array}{c}\text { Highest } \\
\text { BCCB }\end{array}$ \\
\hline P6010 & $12 / 15 / 95$ & 9.2 & 30 & PBCCB
\end{tabular}

\section{Milestone Description}

Complete technical baseline suite to implement the PA.

\section{Milestone Completion Criteria}

This milestone will be complete when all the program requirements documents that identify CRWMS system requirements are approved by the Program Baseline Change Control Board (PBCCB). Documents include: the CRWMS Requirements Document (CRD), the Transportation System Requirements Document (TRANS-SRD), the Storage Requirements Document (STORAGE-SRD), the Mined Geologic Disposal System Requirements Document (MGDS-SRD), and the Waste Acceptance Requirements Document (WA-SRD). 


\begin{tabular}{lcccc}
$\begin{array}{l}\text { Milestone } \\
\text { Number }\end{array}$ & Baseline Date & WBS & $\begin{array}{c}\text { Responsible RW } \\
\text { Organization }\end{array}$ & $\begin{array}{c}\text { Highest } \\
\text { BCCB }\end{array}$ \\
\hline P6020 & $4 / 30 / 96$ & 9.2 & 30 & PBCCB
\end{tabular}

\section{Milestone Description}

Complete total system description update.

\section{Milestone Completion Criteria}

This milestone will be complete when the following documents are complete and approved by the Program Director. Documents include: the revision to the Conceptual System Description and the associated CRWMS Concept of Operations.

\begin{tabular}{lcccc}
$\begin{array}{l}\text { Milestone } \\
\text { Number }\end{array}$ & Baseline Date & WBS & $\begin{array}{c}\text { Responsible RW } \\
\text { Organization }\end{array}$ & $\begin{array}{c}\text { Highest } \\
\text { BCCB }\end{array}$ \\
\hline P7000 & $1 / 30 / 97$ & 9.2 & 30 & PBCCB
\end{tabular}

\section{Milestone Description}

Complete interface control document suite to implement the PA.

\section{Milestone Completion Criteria}

This milestone will be complete when the requisite interface documentation has been approved by the OCRWM Interface Control Working Group for implementation by the design organizations. Documents include: the Storage - Transportation Interface Control Document (ICD), the Waste Acceptance - Transportation ICD, the MGDS - Transportation ICD, the Storage - MGDS ICD, the Storage - Waste Acceptance ICD, and the MGDS - Waste Acceptance ICD. 


\section{WBS: Human Resources \& Administration}

\begin{tabular}{llccc}
$\begin{array}{l}\text { Milestone } \\
\text { Number }\end{array}$ & Baseline Date & WBS & $\begin{array}{c}\text { Responsible RW } \\
\text { Organization }\end{array}$ & $\begin{array}{c}\text { Highest } \\
\text { BCCB }\end{array}$ \\
\hline PA640 & Annual: May & 9.3 & 10 & PBCCB
\end{tabular}

\section{Milestone Description}

Transmit OCRWM Annual Report to Congress.

\section{Milestone Completion Criteria}

After the Secretary approves the document and transmittal letters, RW-1 signs the document and letters.

\begin{tabular}{lcccc}
$\begin{array}{l}\text { Milestone } \\
\text { Number }\end{array}$ & Baseline Date & WBS & $\begin{array}{c}\text { Responsible RW } \\
\text { Organization }\end{array}$ & $\begin{array}{c}\text { Highest } \\
\text { BCCB }\end{array}$ \\
\hline PA620 & Annual: Jan & 9.3 & 10 & PBCCB
\end{tabular}

\section{Milestone Description}

Submit NWF Financial Statements to CR.

\section{Milestone Completion Criteria}

RW-1 signs the letter transmitting the NWF Financial Statement to CR-1. 
APPENDIX G

LONG-TERM REFERENCE SCHEDULE

Revision 5 
INTENTIONALLY LEFT BLANK

Revision 5 
WBS: Repository

\begin{tabular}{lcccc}
$\begin{array}{l}\text { Milestone } \\
\text { Number }\end{array}$ & Baseline Date & WBS & $\begin{array}{c}\text { Responsible RW } \\
\text { Organization }\end{array}$ & $\begin{array}{c}\text { Highest } \\
\text { BCCB }\end{array}$ \\
\hline R4390 & 2004 & 1.2 .4 & YMSCO & PBCCB
\end{tabular}

\section{Milestone Description}

Receive Repository Construction Authorization

\section{Milestone Completion Criteria}

This milestone will be complete when the Director, OCRWM, authorizes construction activities to begin. Prerequisites include a readiness review, NRC construction authorization, and ESAAB approval.

\begin{tabular}{lcccc}
$\begin{array}{l}\text { Milestone } \\
\text { Number }\end{array}$ & Baseline Date & WBS & $\begin{array}{c}\text { Responsible RW } \\
\text { Organization }\end{array}$ & $\begin{array}{c}\text { Highest } \\
\text { BCCB }\end{array}$ \\
\hline R4490 & 2010 & 1.2 .4 & YMSCO & PBCCB
\end{tabular}

Milestone Description

Start Repository Waste Emplacement

\section{Milestone Completion Criteria}

This milestone will be complete when the Secretary of Energy authorizes waste emplacement operations to begin. Prerequisites include a design review, NRC license to receive and possess waste, and ESAAB approval. 
WBS: Regulatory

Milestone

Number

Baseline Date

WBS

Responsible RW

Highest

R5291

$\mathbf{r}$

2008

1.2.5

Organization

BCCB

YMSCO

PBCCB

\section{Milestone Description}

Submit Updated Repository LA to Receive and Possess Waste

\section{Milestone Completion Criteria}

This milestone will be satisfied by the substantial completion of the construction of the surface and underground facilities needed for operations and the submittal of the updated license application to the NRC, in accordance with 10 CFR 60.24.

\begin{tabular}{lcccc}
\hline $\begin{array}{l}\text { Milestone } \\
\text { Number }\end{array}$ & Baseline Date & WBS & $\begin{array}{c}\text { Responsible RW } \\
\text { Organization }\end{array}$ & $\begin{array}{c}\text { Highest } \\
\text { BCCB }\end{array}$ \\
\hline TBD & 2110 & 1.2 .5 & YMSCO & PBCCB
\end{tabular}

\section{Milestone Description}

Submit License Application for Amendment to Permit Repository Closure

\section{Milestone Completion Criteria}

To be determined. 
WBS: Casks

\begin{tabular}{lcccc}
$\begin{array}{l}\text { Milestone } \\
\text { Number }\end{array}$ & Baseline Date & WBS & $\begin{array}{c}\text { Responsible RW } \\
\text { Organization }\end{array}$ & $\begin{array}{c}\text { Highest } \\
\text { BCCB }\end{array}$ \\
\hline $\mathrm{T} 1600$ & 2010 & 3.2 .2 & 46 & PBCCB
\end{tabular}

\section{Milestone Description}

Transportation System Fully Operational

\section{Milestone Completion Criteria}

This milestone will be complete when the full operational testing of the objective Transportation System has been completed.

\begin{tabular}{lcccc}
$\begin{array}{l}\text { Milestone } \\
\text { Number }\end{array}$ & Baseline Date & WBS & $\begin{array}{c}\text { Responsible RW } \\
\text { Organization }\end{array}$ & $\begin{array}{c}\text { Highest } \\
\text { BCCB }\end{array}$ \\
\hline T1297 & 2007 & 3.2 .3 & 46 & ESAAB
\end{tabular}

\section{Milestone Description}

Start Fabrication of GA-4/GA-9 LWT Casks for Fleet

\section{Milestone Completion Criteria}

This milestone will be complete when the fabrication contract has been awarded. 
INTENTIONALLY LEFT BLANK 